University of Chicago Law School

Chicago Unbound

Journal Articles

Faculty Scholarship

1990

\title{
The Doctrine of Commercial Impracticability in a Second-Best World
}

Alan O. Sykes

Follow this and additional works at: https://chicagounbound.uchicago.edu/journal_articles

Part of the Law Commons

\section{Recommended Citation}

Alan O. Sykes, "The Doctrine of Commercial Impracticability in a Second-Best World," 19 Journal of Legal Studies 43 (1990).

This Article is brought to you for free and open access by the Faculty Scholarship at Chicago Unbound. It has been accepted for inclusion in Journal Articles by an authorized administrator of Chicago Unbound. For more information, please contact unbound@law.uchicago.edu. 


\title{
THE DOCTRINE OF COMMERCIAL IMPRACTICABILITY IN A SECOND-BEST WORLD
}

\author{
ALAN O. SYKES*
}

$\mathrm{O}$

RDINARILY, a promisor who fails to perform a contractual obligation must pay damages to the promisee for breach of contract. But if the promisor is "unable" to perform because an extraordinary contingency materializes, and the promisor has not expressly assumed the risk of that contingency, the courts may relieve the promisor of the obligation to perform. At common law, such decisions fall under the doctrine of "impossibility." The Uniform Commercial Code (U.C.C.) adopts the term "impracticability", which, for convenience, is used throughout this article to refer to both U.C.C. and common-law doctrine.

This article explores the conditions under which a discharge of contractual obligations is efficient following an event that makes performance "impracticable," such as an extraordinary increase in the cost of per-

* Assistant Professor of Law, University of Chicago Law School. Portions of this article are adapted from the second essay of my doctoral thesis. I thank my thesis advisers, Sidney Winter, Alvin Klevorick, and John Bigelow, for many insights and suggestions. I also thank Douglas Baird, Richard Craswell, Richard Posner, and Alan Schwartz for valuable comments on a prior draft. Special thanks are due to Shawn Bentley for able research assistance. Finally, I am grateful to the Lynde and Harry Bradley Foundation for financial support.

' See, for example, John Calamari \& Joseph Perillo, The Law of Contracts 475-509 (2d ed. 1977). The doctrines of "frustration" and "mutual mistake" are closely related. See $i d$. at 299-311, 495-96.

The first cases to recognize a defense of "impossibility" involved personal services contracts that could not be performed due to the death of the promisor. Then, in Taylor $v$. Caldwell, 3 Best \& S. 826 (Q.B. 1863), discussed below in Section IIB, the impossibility defense was expanded to encompass contracts that could not be performed due to the destruction of property essential to performance. Subsequent decisions extended the defense to contracts that could not be performed because performance had become illegal subsequent to the negotiation of the contract ("supervening illegality"). See, for example, Horowitz v. United States, 267 U.S. 458 (1925); Fisher v. U.S. Fidelity \& Guaranty Co., 313 IIl. App. 66, 39 N.E.2d 69 (1942).

2 See U.C.C. $\$ 2-615$.

[Journal of Legal Studies, vol. XIX (January 1990)]

(๔) 1990 by The University of Chicago. All rights reserved. 0047-2530/90/1901-0008\$01.50 
formance. Section I of the article analyzes in detail the following paradigm case: a promisor agrees to deliver some good or service to the promisee at a specified future date. At the time of contracting, uncertainty exists as to the primisor's cost of production. Subsequently, after this uncertainty has been resolved, the promisor must decide whether to perform or to commit a breach of the agreement, and, in the event of breach, a court must decide what damages (if any) to award to the promisee. Following the analytical approach of Shavell, Rogerson, and others, Section I considers whether the impracticability defense may supply a second-best risk-sharing device in such cases and whether it may serve to optimize reliance expenditures by the promisee or to optimize the incentives for mitigation of damages. It further considers how the impracticability defense may affect the promisor's incentives to lay off risk efficiently in the marketplace, to disclose information about the likelihood of nonperformance to the promisee, and to take measures to avoid the event that makes performance impracticable. The analysis suggests conditions under which the impracticability defense is efficient and further argues that the information necessary to identify those conditions in practice may be extraordinarily difficult to explain.

Section II examines a number of leading cases in which the impracticability defense has been successful, and, where necessary, it extends the analysis developed in Section I to encompass circumstances that do not cleanly fit the assumptions of the paradigm case. Although the discussion of the case law is necessarily selective, Section II argues that legal doctrine is, on its face, quite insensitive to the economic factors that determine whether a discharge of the promisor's obligations is efficient. It thus questions the efficiency of the impracticability defense in practice and argues that, at least for many important classes of cases, the information necessary to improve on the efficiency of the defense will rarely, if ever, be available to the courts. The analysis thereby raises the possibility that the impracticability defense often simply introduces uncertainty into the contracting process ex ante, and fosters greater litigation costs ex post, with little or no offsetting economic benefits. ${ }^{3}$

\section{Economic Analysis}

This section will inquire whether and under what circumstances a discharge of the promisor's obligations constitutes an efficient allocation of

${ }^{3}$ Although cases of "frustration" and "mistake" raise issues that are closely related to those discussed in this article, the economic and legal analysis omits express consideration of such cases. Thus, particularly with regard to the critique of existing law that is developed in Section II, the analysis here has little to say about the efficiency of legal doctrine regarding frustration and mistake. 
the risks attendant on contingencies that increase the cost of performance. Except where noted, the term "efficiency" means "Pareto optimality" from the perspective of the parties to the contract.

The analysis will assume that contracting parties appreciate ex ante the contingencies to which the impracticability defense will apply and make an informed choice whether to incur the transaction costs necessary to negotiate an express allocation of risk or instead to accept the impracticability defense as an "off-the-rack" substitute. Thus, like the analyses of Posner and Rosenfield ${ }^{4}$ and other writers, 5 the discussion inquires whether the impracticability defense can enhance the contracting parties' ex ante welfare by replicating in rough fashion the distribution of risk that they would negotiate for themselves in the absence of transaction costs.

\section{A. Risk Sharing}

As previous writers have suggested, the impracticability defense might be justified as a way to shift the risk of cost increases to the promisee when the promisor is relatively more risk averse or relatively less able to diversify risk. ${ }^{6}$ Accordingly, the analysis to follow develops some basic results about the effects of the impracticability defense ${ }^{7}$ on the efficiency of risk sharing. The results here, and their elaboration in Section II, cast considerable doubt on the assertion that the impracticability defense can (or does) do much to enhance the efficiency of risk sharing between contracting parties in practice.

4 Richard Posner \& Andrew Rosenfield, Impossibility and Related Doctrines in Contract Law: An Economic Analysis, 6 J. Legal Stud. 83 (1977).

5 The literature on impossibility and related doctrines is considerable, with economic concerns emphasized to greater or lesser degree in many of the articles. See Paul Joskow, Commercial Impossibility: The Uranium Market and the Westinghouse Case, $6 \mathrm{~J}$. Legal Stud. 119 (1977); Christopher Bruce, An Economic Analysis of the Impossibility Doctrine, 11 J. Legal Stud. 311 (1982); Jeffrey Perloff, The Effects of Breach of Forward Contracts due to Unanticipated Price Changes, 10 J. Legal Stud. 221 (1981); Alan Schwartrz, Sales Law and Inflations, 50 So. Cal. L. Rev. 1 (1976); Michelle White, Contract Breach and Contract Discharge due to Impossibility: A Unified Theory, 17 J. Legal Stud. 353 (1988); Victor Goldberg, Impossibility and Related Excuses, 144 J. Int'l \& Theoretical Econ. 100 (1988).

Interesting articles on closely related topics include A. Mitchell Polinsky, Fixed Price versus Spot Price Contracts, 3 J. L. Econ. \& Org. 27 (1987); A. Mitchell Polinsky, Risk Sharing through Breach of Contract Remedies, 12 J. Legal Stud. 427 (1983); Victor Goldberg, Price Adjustments in Long-Term Contracts, 1985 Wisc. L. Rev. 527; Anthony Kronman, Mistake, Disclosure, Information, and the Law of Contracts, 7 J. Legal Stud. 1 (1978); and Clayton Gillette, Commercial Rationality and the Duty to Adjust Long-Term Contracts, 69 Minn. L. Rev. 521 (1985).

6 See, for example, Posner \& Rosenfield, supra note 4.

${ }^{7}$ The impracticability defense under the U.C.C. applies only to the sale of goods; if the contract involves the sale of a service, the common-law impossibility defense will apply. Henceforth, this article will use the term "impracticability defense" to encompass both the U.C.C. and the common-law defenses. 


\section{Prior Literature}

Much of the economic literature on remedies for breach of contract analyzes rules of nonliability (discharge) and compares the efficiency of nonliability to alternative damages measures. ${ }^{8}$ Under the rules of nonliability considered in this literature, however, the promisor is never held liable for a breach. The impracticability defense, by contrast, is a rule of "contingent" discharge-as modeled below, the promisor is liable for damages if his cost of production falls below the threshold for discharge but will incur no liability if cost is above that threshold. Thus, the impracticability defense might be characterized as a two-tier damages rule. Prior formal analyses of contract damages have not addressed the efficiency of such two-tiered rules.

Other writers have analyzed how the risk of cost increases should be allocated between the promisor and the promisee to promote efficient risk sharing. Polinsky ${ }^{9}$ and White ${ }^{10}$ analyze a model in which the promisor's cost of production may increase to the point that performance becomes inefficient. They use the model to derive the efficient level of "damages" contingent on such a cost increase and an attendant breach by the promisor. The analysis to follow differs from that of Polinsky and White in two important respects. First, both Polinsky and White derive results about the first-best level of damages. Except in the case of the risk-neutral promisor, however, the first-best damage measure does not resemble any damage measure actually employed by the courts. The objective here, by contrast, is to compare the efficiency of discharge under the impracticability defense to the damage measure most commonly employed by the courts (expectation damages) and, thus, to ascertain whether existing legal doctrine may be understood as a second-best mechanism for risk allocation under the conditions of limited information that the courts must confront. Second, Polinsky and White consider only a two-state model in which the cost of production may assume two possible values. Here, the cost of production has a continuous probability distribution. This extension is an important one, as it allows consideration of the difficulties that arise in any effort to set an efficient threshold of discharge.

\footnotetext{
${ }^{8}$ See, for example, John Barton, The Economic Basis of Damages for Breach of Contract, 1 J. Legal Stud. 277 (1972); Peter Diamond \& Eric Maskin, An Equilibrium Analysis of Search and Breach of Contract, I: Steady States, 10 Bell J. Econ. 282 (1979); Steven Shavell, Damage Measures for Breach of Contract, 11 Bell J. Econ. 466 (1980); William Rogerson, Efficient Reliance and Damage Measures for Breach of Contract, 15 Rand J. Econ. 39 (1984); Jeffrey Perloff, Breach of Contract and the Foreseeability Doctrine of Hadley v. Baxendale, 10 J. Legal Stud. 39 (1981).

${ }^{9}$ Polinsky, Risk Sharing, supra note 5.

${ }^{10}$ White, supra note 5.
} 


\section{The Model}

Consider a contract in which a promisor (hereafter the "producer") agrees to supply the promisee (hereafter the "buyer") with one unit of a specialized good or service. The cost of production, $c$, is a random variable at the time of contracting, although the continuous probability distribution of $c$ is known to both parties and given by $F(c)$. The corresponding probability density function is $f(c)$. It is certain that $c$ will fall within a range of $k$ to $K$.

The producer and buyer are expected utility maximizers, and each is either risk neutral or risk averse. Their Von Neumann-Morgenstern utility functions are, respectively, $u(\hat{w})$ and $v(\tilde{w}) .{ }^{11}$

For simplicity, assume that the gross value to the buyer of performance under the contract is a fixed amount, $V$. Thus, for example, the model does not allow for the possibility that the value of the contract to the buyer might increase with the cost of performance. ${ }^{12}$ The price to be paid by the buyer on delivery of output is $r$, and hence the net value of the contract to the buyer is $V-r .^{13}$

Uncertainty about the cost of performance is resolved after the contract is signed but before the commencement of performance. The value of the contract to the buyer, $V$, may or may not exceed the cost of performance. Thus, $V<K$, and the realized value of $c$ may exceed $r$, the payment to the producer for performance.

The producer and buyer each have "outside" wealth-wealth that they possess regardless of whether they enter the contract-equal to $y$ and $m$, respectively. Assume for the moment that the buyer makes no reliance expenditures. Also, assume for now that increases in the cost of performance are both uninsurable and unhedgeable by the producer and that the buyer cannot insure against or otherwise mitigate the damages from nonperformance. Thus, the buyer has no opportunity to secure an alternative supply of the good or service if the producer commits a breach.

\section{The Impracticability Defense as a Second-best Rule}

In this simple model, uncertainty exists only with respect to the producer's cost of performance. If the transaction costs of contracting were zero, the parties would negotiate a customized allocation of the risk of

11 See John Von Neumann \& Oscar Morgenstern, Theory of Games and Economic Behavior 15-29 (1944); Hal Varian, Microeconomic Analysis 104-111 (1978).

12 See the discussion of the crop-failure cases in Section II for an intuitive discussion of the possible consequences of relaxing this assumption.

13 All events occur during one period, so that discounting to present value is unnecessary. 
cost-of-performance fluctuations. Such a customized allocation could be accomplished simply by allowing the price paid by the buyer, $r$, to depend on the cost of performance. Under the usual assumption that the parties would negotiate a Pareto-efficient contract (from their perspective), the customized price schedule, $r(c)$, would distribute the risk of cost fluctuations to the mutual advantage of the parties in accordance with their attitudes toward risk bearing. The Pareto-efficient contract would also require the producer to perform only if the cost of performance, $c$, was no greater than the value of performance, $V$. In the event that $c>V$, the contract might require the producer to pay "damages" to the buyer (although "damages" might be negative if the buyer was the efficient risk bearer with respect to the risk of nonperformance). The price schedule, $r(c)$, could serve that function as well. Depending on the circumstances, therefore, the Pareto-efficient price schedule-hereafter called the "firstbest" schedule-would depend in potentially complex fashion on the parties' utility functions, their outside wealth, the gross benefits of performance, and the distribution of surplus from the contract. ${ }^{14}$

By hypothesis, however, the contracting parties fail to write a first-best contract because of transaction costs. ${ }^{15}$ Suppose instead that the parties negotiate a contract with a fixed price equal to $r$, containing no provision to allocate the risk of fluctuations in the cost of performance or the risk that performance becomes inefficient. ${ }^{16}$ The assumption of a fixed-price contract is not unrealistic, for, as Section II will indicate, the most com-

${ }^{14}$ The assumption that $r(c)$ would be Pareto efficient permits ready characterization of the price schedule that the parties would select-it would be chosen so that the marginal rates of substitution between dollars in different states of nature (different realizations of $c$ ) were the same for the producer and the buyer. See Karl Borch, The Safety Loading of Reinsurance Premiums, 43 Skandanavisk Aktuarietidsskrift 163 (1960); Kenneth Arrow, Uncertainty and the Welfare Economics of Medical Care, in Essays on the Theory of Risk Bearing 177, 21718 (1974); Steven Shavell, Sharing Risks of Deferred Payment, 84 J. Pol. Econ. 161 (1976). The implications of this condition for the optimal allocation of the risk of fluctuations in the cost of performance are explored in Polinsky, Risk Sharing, supra note 5, at 441-44; and White, supra note 5 .

15 Transaction costs include not only the costs of negotiation but also certain costs of enforcing the bargain. For example, the contract that the parties would write for themselves in the absence of transaction costs might embody a price that varied depending on the realized value of $c$. But that value of $c$ may be known only to the producer, and the buyer may be unwilling to accept a price schedule conditioned on $c$ out of fear that the producer will not make truthful disclosure of its value. See Shavell, supra note 8.

${ }^{16}$ The fact that the parties negotiate a fixed-price contract does not necessarily imply that an assignment of risk to the producer is optimal. It may be evidence that the producer is better suited than the consumer to bear the risk of cost fuctuations, or it may simply reflect the transaction costs of negotiating or enforcing a superior device for the allocation of riska fixed-price agreement is surely the cheapest type of agreement to conclude. 
monly litigated cases involve sellers whose fixed-price contracts have become highly unprofitable. ${ }^{17}$

After the fixed-price agreement has been negotiated, the uncertainty about the producer's cost of production will be resolved. Suppose that the producer then refuses to perform because the cost of performance to the producer, $c$, greatly exceeds the payment to the producer for performance, $r$. What remedy should a court afford to the buyer?

Perhaps the court might reform the contract to replicate the outcome that the parties would have negotiated for themselves in the absence of transaction costs. That is, the court might adjust the terms of the contract so that, given the realization of $c$, the producer would receive the value of $r(c)$ that he would receive under the first-best price schedule. ${ }^{18}$

Even if the court were capable of ascertaining the first-best price schedule, however, it is not Pareto efficient in general to adjust the contract price to accord with that schedule for some realizations of $c$ but not others. And, since the parties will not require dispute resolution when $c$ is modest and the producer willingly performs, the opportunity to adjust the contract price will present itself only for some (high) realizations of $c$. Thus, if the court is to adjust the price term efficiently on a case-by-case basis, it should not seek to adjust price in accordance with the first-best price schedule, but instead to adjust it in accordance with a second-best schedule that takes account of the fact that a fixed-price term will prevail for many realizations of $c$.

The efficient price adjustment would still depend, however, on much the same factors as the first-best price schedule-the utility functions of the contracting parties, the probability distribution of $c$, and so on. This observation immediately suggests a much more fundamental problem with these case-by-case price adjustments-the information necessary for a court to ascertain the appropriate adjustment may be unavailable, and, even if it could be obtained, the administrative costs of evaluating it on a case-by-case basis would likely be prohibitive.

Not surprisingly, therefore, courts do not undertake to adjust the contract price case-by-case in this fashion. Instead, when the contract is found to be "silent" about the allocation of the risk of cost increases, and the cost of performance rises to the point of becoming highly unprofitable to the producer, the law affords a rather crude remedy to the producerthe impracticability defense. If the defense applies, the producer's obliga-

17 Section II also contains an intuitive discussion of how the presence of an escalator provision in the contract might affect the analysis-see the discussion of the Alcoa case.

18 This seems, roughly, to be the sort of approach advocated in White, supra note 5 . 
tions are discharged along with the buyer's obligation to pay for performance. If the defense does not apply, the producer is subject to conventional measures of damages in the event of a breach.

Unquestionably, this legal regime does not replicate what the parties would negotiate for themselves in the absence of transaction costs. ${ }^{19}$ Nor does it correspond in general to the second-best price adjustment that a court might make if the necessary information were available. But information constraints inevitably force the legal system to choose among rules that would not otherwise be ideal. Thus, the pertinent inquiry is not whether existing law is first-best efficient, or even second-best efficient under conditions of full information, but whether some feasible alternative to existing law would be more efficient.

To that end, the analysis to follow explores the circumstances in which the impracticability defense may supply a second-best rule under conditions of limited information. The search for a second-best rule must begin, of course, with a specification of the set of feasible alternatives from which the courts may choose. The analysis will assume that, because of administrative costs, legal rules that entail price adjustment and loss splitting are infeasible-indeed, such rules are generally absent in the law. ${ }^{20}$ Rather, the only possible response to impracticability is a discharge of the parties' obligations. For simplicity, the analysis will further exclude consideration of cases in which specific performance, restitution, or reliance damages might be an appropriate remedy. Rather, the single alternative to discharge under the impracticability defense is the expectation damages rule. ${ }^{21}$

The expectation measure requires the breaching party to place the nonbreaching party in the position that he would have attained had the contract been performed. In the simple model above with a fixed-price contract, this measure of damages is equal to $V-r$ in the event of a breach by the producer. ${ }^{22}$ Hence, with the expectation-damages rule in force, the producer receives $r-c$ if he performs the contract and pays $V-r$ in the event of a breach. Assuming, for convenience, that the producer performs when he is indifferent between performance and

19 See, for example, Posner \& Rosenfield, supra note 4, at 113-14; White, supra note 5.

${ }^{20}$ Other writers explain the absence of loss-splitting rules in the law as a consequence of administrative costs. See Posner \& Rosenfield, supra note 4, at 113-14.

${ }^{21}$ On the merits of the expectation measure in relation to possible alternatives, see generally Richard Epstein, Beyond Foreseeability: Consequential Damages in the Law of Contract, 18 J. Legal Stud. 105 (1989).

${ }^{22}$ Under the principle of Hadley v. Baxendale, damages are limited to losses reasonably foreseeable by the promisor. See, for example, Calamari \& Perillo, supra note 1, at 523 et seq. The analysis here assumes that all of the consumer's losses are foreseeable. 
breach, he will perform if $c \leq V$ and breach if $c>V$. The expectationdamages rule thus implements one important aspect of the contract that the parties would write for themselves in the absence of transaction costs-it induces an efficient breach whenever $c>V$ and encourages performance otherwise. ${ }^{23}$

But the expectation measure of damages fails to implement another potentially important feature of that contract-risk sharing between the parties. The buyer receives $V-r$ with certainty, and the producer bears the entire risk of an increase in the cost of production over the range $k$ to $V$. The question then arises whether and under what circumstances a discharge of the producer's obligations under the impracticability defense may be superior to the expectation damages rule because of its ability to shift risk to the buyer.

The analysis makes the following assumption about the information available to courts: courts can make only general, qualitative assessments regarding the attitudes toward risk bearing of the contracting parties. Thus, it is assumed that a court can identify parties who are likely to be approximately risk neutral and parties who are likely to be risk averse. But courts are assumed not to know (and not to have the capacity to discover at reasonable cost) the precise utility functions of contracting parties, the exact probability distribution of $c$, and similar details about each case. Hence, the remarks to follow focus on the question whether information that is limited to general, qualitative knowledge about attitudes toward risk bearing can be applied usefully in choosing between discharge and expectation damages in the event of a breach by the producer.

\section{Formulations of the Second-best Problem}

One way to formulate the choice between the impracticability defense and expectation damages is as follows: let $d$ represent damages payable by the breaching party (in this case the producer). Then

$$
d=V-r \text { if } c \leq B,
$$

and

$$
d=0 \quad \text { if } c>B,
$$

where $B$ is a parameter chosen by the law from the interval $[k, K]$ - the range of possible realizations of $c$. Under such a rule, if the cost of production is small enough, a breach by the producer obligates him to pay

${ }^{23}$ This is a familiar result. See, for example, Shavell, supra note 8, at 478. 
the expectancy measure of damages. But if the cost of production is large enough, the contract is discharged. Of course, a choice of $B=K$ precludes discharge and is equivalent to imposing the expectation measure of damages whatever the realized value of $c$. This representation of the impracticability defense suggests one formulation of the second-best optimization problem-with the knowledge that the contracting parties will negotiate a fixed-price contract, the law must choose $B$ to maximize their ex ante welfare. Hereafter, this formulation of the problem is termed the "general formulation."

As shall be seen, however, the problem of choosing the optimal value of $B$ in the general formulation requires much the same information as the problem of adjusting the contract price in accordance with a second-best, full-information price schedule as described above. Thus, the general formulation strains the earlier assumption that administrative costs foreclose the use of price adjustment and loss-splitting rules. For this reason, the analysis to follow will also consider a simplified formulation of the second-best optimization problem. In particular, it will inquire whether and when an impracticability defense that simply sets $B=V$ can dominate the expectation damages rule. Such an impracticability defense requires the producer to pay expectation damages if he commits a breach when performance remains efficient. But if he commits a breach when performance is no longer worthwhile, the contract is discharged.

\section{The Second-best Optimum}

In the general formulation of the second-best problem, any Paretooptimal value of $B$ concurrent with the parties' choice of $r$ (which, of course, depends on the value of $B$ announced by the law) must maximize $E u(\hat{w})$ subject to the constraint that $E v(\tilde{w})$ attains some fixed value $v^{*} \cdot{ }^{24}$ In the simplified formulation, the issue is whether $B=V$ or $B=K$ provides greater utility to the producer, holding the expected utility of the buyer constant at $v^{*} .^{25}$

This section presents an intuitive discussion of the factors that affect the determination of the second-best optima. A more formal analysis of

\footnotetext{
24 Alternatively, of course, the utility of the buyer could be maximized subject to a constraint on the utility of the producer.

${ }^{25}$ In both formulations, the complete set of Pareto-optimal contracts may be derived by varying the value of $v^{*}$. If the buyer is to accept a particular contract within this set, that contract must provide an expected utility at least equal to the buyer's reservation utility, $v(m)$. Likewise, if the producer is to accept a particular contract within this set, that contract must provide an expected utility at least equal to the producer's reservation utility, $u(y)$. Contracts that provide both parties with at least their reservation utility are said to be within the core of the bargaining game. Henceforth, it is assumed that the core is nonempty.
} 
the model is developed briefly in an appendix, along with proofs and illustrations of a few central results. (This appendix is available from the author on request.)

Consider first the conditions under which the producer will commit a breach. For any realized value of $c$, the utility of the producer is

$$
\begin{aligned}
u(\hat{w}) & =u(y+r-c) & & \text { if he performs, } \\
& =u(y-d) & & \text { if he does not perform, }
\end{aligned}
$$

where the damages variable, $d$, is defined as above. The corresponding utility of the buyer is

$$
\begin{aligned}
v(\bar{w}) & =v(m+V-r) & & \text { with performance, } \\
& =v(m+d) & & \text { with nonperformance. }
\end{aligned}
$$

Clearly, a breach is advantageous to the producer whenever

$$
y+r-c<y-d .
$$

Thus, irrespective of the value of $B$, breach never occurs if $r-c>0$ or, by assumption, when $r-c=0$.

When $r-c$ is negative, breach will occur if $r-c<-d$. Thus, whenever $c>B$, breach will surely occur, and when $c \leq B$, breach will occur if $r-c<-(V-r)$, which implies $c>V$. This analysis suggests two cases, which differ according to whether $B$ is greater than or less than $V$.

First, when the value of $B$ is chosen to exceed $V$, breach will occur if and only if $c>V$, the condition for efficient breach. For values of $c$ above $V$ and below $B$, the producer will pay expectation damages, $V-r$. For realizations of $c$ greater than $B$, the contract is discharged and damages are zero.

In the second case, the value of $B$ is chosen to be less than $V$. Hence, there exist realizations of $c$ above $B$ but below $V$ for which performance is efficient. But a breach will nonetheless occur whenever $c>B$, unless the buyer renegotiates the contract at that point to obtain performance. ${ }^{26}$ Consequently, the effect on the welfare of the contracting parties of a value of $B$ less than $V$ turns partly on whether renegotiation will occur in the event that $B<c<V$. The prospects for renegotiation depend, of course, on the cost of renegotiation in relation to its anticipated value to the parties. Sometimes those costs will exceed the anticipated benefits of renegotiation, and sometimes they will not. The remarks to follow will

\footnotetext{
${ }^{26}$ For a model of contracting behavior that embodies renegotiation, see Rogerson, supra note 8 .
} 
note how the presence or absence of renegotiation may affect the analysis.

a) Risk-neutral Producer. If the producer is risk neutral,${ }^{27}$ both the general and the simplified formulations of the second-best problem yield to a simple proposition: a choice of $B<K$ cannot improve the welfare of the contracting parties and can assuredly decrease it. Thus, the expectation damages rule is always at least as efficient as any version of the impracticability defense. ${ }^{28}$

This proposition is quite intuitive: a choice of $B=K$ is equivalent to imposing the expectation damages rule on the producer, whatever the realization of $c$. This circumstance provides the producer with an incentive to commit a breach if and only if a breach is efficient. Moreover, by hypothesis, the contracting parties negotiate a fixed-price contract at a price $r$. Thus, with $B=K$, the buyer enjoys a return on the contract of $V-r$ with certainty. All risk of cost fluctuations is borne by the producer, who is at least as efficient as the buyer at bearing this risk by the assumption that the producer is risk neutral.

This discussion immediately suggests two reasons why a choice of $B<K$ might reduce the parties' welfare relative to a choice of $B=K$. First, suppose not only that $B<K$ but also that $B<V$. Then, as explained above, the producer will elect not to perform in the absence of renegotiation whenever the realized value of $c$ exceeds $B$, even if $c<V$ and performance remains efficient. Such a choice of $B$ creates the possibility of inefficient breach, which reduces the combined expected wealth of the contracting parties. Yet, if the producer is risk neutral, a Pareto-optimal contract must maximize the combined expected wealth of the parties. ${ }^{29}$ Furthermore, even if renegotiation would avoid an inefficient breach, a welfare loss would still arise to the extent that renegotiation was costly.

Second, a choice of $B<K$ (whether or not $B<V$ ) places risk on the buyer, because, if $c>B$, the buyer will lose some or all of the benefits of performance. With $B=K$, by contrast, the buyer receives $V-r$ with certainty. Hence, if the buyer is at all risk averse, a choice of $B<K$ reduces welfare by allocating risk inefficiently to the risk-averse buyer instead of to the risk-neutral producer.

A value of $B<K$ can be nonuniquely optimal if (a) both the buyer and

${ }^{27}$ Alternatively, the producer may be risk averse but have the ability to diversify fully the risk of cost fluctuations.

${ }^{28}$ Formal proof is omitted but follows readily from the necessary conditions for optimality in the general formulation of the second-best problem. These may be found in section 1 of a formal appendix, which is available on request from the author. Hereafter, all citations to the appendix refer to this formal appendix.

29 See Shavell, supra note 8. 
producer are risk neutral, and $(b) B \geq V$. But a choice of $B=K$ is assuredly just as good.

b) Risk-averse Producer and Risk-neutral Customer. Intuitively, the impracticability defense seems most likely to enhance the parties' welfare when the producer is risk averse and the buyer is risk neutral. Under these conditions, the expectation damages rule insulates the risk-neutral party from risk and places all risk on the risk-averse party. An opportunity thus arises for considerable improvement in the efficiency of risk allocation.

Perhaps surprisingly, however, it is not possible to show that the impracticability defense (a choice of $B<K$ ) always improves welfare under these conditions. Without further assumptions about the producer's utility function or the probability distribution of $c$, even a risk-averse producer may prefer the expectation damages rule. The reason, put simply, is that the impracticability defense does not merely reduce "risk" for the producer ${ }^{30}$ Consider a small reduction of $B$ to a value slightly less than $K$. The effect is to reduce slightly the probability of the most adverse outcome for the producer-the payment of expectation damages equal to $V-r$-and to increase commensurately the probability of a better outcome in which "damages" are zero. But the producer must compensate the risk-neutral buyer for this change in the distribution of returns with a reduction in the contract price, $r$, to hold the expected wealth of the buyer constant. Thus, while the probability of the most adverse outcome for the producer is slightly reduced, all other outcomes for the producer are adversely affected. The "worst-case scenario" for the producer is thus more unfavorable under the impracticability defense-for realizations of $c$ between $V$ and $B$, he still pays expectation damages equal to $V-r$, but $r$ is smaller under the impracticability defense, and thus $V-r$ is larger. Without further assumptions, it is not clear whether the risk-averse producer will prefer this change in the distribution of his returns. ${ }^{31}$

The same difficulty arises with respect to the simplified formulation of the second-best problem. That is, without further assumptions, it is not

30 On the economic meaning of "risk," see Michael Rothschild \& Joseph Stiglitz, Increasing Risk I: A Definition, 2 J. Econ. Theory 225 (1970). In the terminology of Rothschild and Stiglitz, the distribution of returns to the producer would be riskier under the expectation damages rule than under the impracticability defense if both distributions had the same mean (as they do with $B \geq V$ and a risk-neutral buyer) and if the latter distribution would be preferred to the former distribution by any risk averter.

${ }^{31}$ One such assumption is that the marginal utility function for the producer is concave (the marginal utility of wealth decreases at a nondecreasing rate). This condition is sufficient to ensure that $B=K$ is not a second-best optimum under the general formulation. See the appendix, section 2 . 
possible to show that a risk-averse producer will always prefer $B=V$ to $B=K$.

An assumption that facilitates the derivation of more definitive results is the assumption that "risk" for the producer is adequately captured by the variance of returns. Utilizing this assumption, one can derive the following results: ${ }^{32}$ first, a reduction in $B$ from $B=K$ to a value $B=K-$ $\delta>V$ reduces the variance of the producer's returns for sufficiently large $\delta$, holding the expected utility of the buyer constant - thus, $B=K$ cannot be optimal in the general formulation of the second-best problem. Moreover, under conditions that are likely to hold for many contracts, variance falls monotonically as $\delta$ increases through the range $K-\delta>V$, so that $B=V$ is typically superior to any choice of $B>V$. Second, a choice of $B=V$ provides the producer with a lower variance of returns than a choice of $B=K$, holding the expected utility of the buyer constantthus, in the simplified formulation of the second-best problem, $B=V$ is the optimum.

The assumption that variance is an adequate measure of risk is common in the finance literature (it underlies the capital asset-pricing model) ${ }^{33}$ and indeed has been employed before in the study of the impossibility defense. ${ }^{34}$ Whether it is an appealing assumption in this context, however, is certainly open to debate. Formally, the assumption that variance adequately measures risk may be justified in two ways: $(a)$ the probability distribution of returns must belong to a certain "two-parameter" family of distributions (which includes the normal), or $(b)$ individual utility functions must be adequately approximated by a quadratic function. ${ }^{35}$ Only the latter justification is potentially applicable here, given the rather peculiar distribution of returns that arises under the impracticability defense. ${ }^{36}$ But the proposition that individual utility functions may be approximated well by a quadratic function is open to a number of criticisms. A quadratic function implies that the marginal utility of wealth is negative at sufficiently high levels of wealth. ${ }^{37}$ It also implies increasing absolute risk

32 See the appendix, sections 3-4.

${ }^{33}$ See, for example, Charles Haley \& Lawrence Schall, The Theory of Financial Decisions, 143-55 (2d ed. 1979).

${ }^{34}$ See Perloff, supra note 8.

${ }^{35}$ See Eugene Fama \& Merton Miller, Theory of Finance 217, 256 (1972).

${ }^{36}$ Even if the random variable $c$ had, say, a normal distribution, the producer's returns from the contract would not. For $c>B$, the producer's return is zero, which concentrates considerable probability mass at that point in the distribution. Likewise, for $V<c \leq B$, the producer will not perform and will pay expectation damages, which concentrates considerable probability mass on the most adverse outcome for the producer.

${ }^{37}$ For the function $u(w)=a w-b w^{2}, a, b>0$, the marginal utility function is $u(w)=a-$ $2 b w$, which plainly turns negative for sufficiently large $w$. 
aversion, contrary to conventional wisdom. ${ }^{38}$ Hence, results about the effect of the impracticability defense on the variance of the producer's returns are at best a rather uncomfortable justification for the defense.

The discussion to this point considers choices of $B \geq V$. In the general formulation of the second-best problem, it is also necessary to inquire whether the optimum may lie in the region $B<V$. Such a choice of $B$ creates the possibility of inefficient breach-for $B<c<V$, the producer will breach even though performance remains efficient, unless the buyer renegotiates to secure performance. If a choice of $B<V$ is to be secondbest optimal, therefore, the benefits of more efficient risk allocation must outweigh the possible costs of inefficient breach or the renegotiation costs to avoid it.

Not surprisingly, it is difficult to develop any general proposition about when the optimal $B$ lies below $V$. Even the assumption that the variance of returns adequately captures "risk" for the producer allows little mileage. About all that can be said is that the second-best optimal value of $B$ may be less than $V$, depending on the producer's utility function, the probability distribution of $c$, and so on. ${ }^{39}$

In summary, the mere existence of risk aversion on the part of the producer does not guarantee that an impracticability defense is superior to the expectation damages rule, even when the buyer is risk neutral. The defense does not simply reduce the "riskiness" of returns to the producer

${ }^{38}$ The coefficient of absolute risk aversion, $-u^{\prime \prime}(w) / u^{\prime}(w)$, measures the extent to which a risk-averse individual will insist on more than fair odds to accept a small bet. Intuitively, the second derivative of the utility function, $u^{\prime \prime}$, captures the degree of concavity of the function and thus the extent to which a reduction in wealth causes a greater loss of utility than the gain in utility from an equal increase in wealth. It is precisely this asymmetry between the effect on utility of equal increases and decreases in wealth that creates risk aversion. But because the utility function is merely a mathematical representation of a preference ordering, the numerical value of utility (and thus the numerical value of $u^{\prime \prime}$ ) has no significance-it can be scaled up or down arbitrarily. The division of $u^{\prime \prime}$ by $u^{\prime}$ thus serves as a deflator to provide a measure of risk aversion that is insensitive to the arbitrarily chosen units of the utility function. Multiplication of the resulting quotient by -1 to obtain the coefficient of absolute risk aversion as expressed above converts the quotient to a positive number ( $u$ " is negative for a concave function). The larger the coefficient of absolute risk aversion, the more risk averse the individual whose preferences are represented by the function $u(w)$, and the more favorable the odds required before a bet will be accepted. See Kenneth Arrow, The Theory of Risk Aversion, in Essays on the Theory of Risk Bearing 90, 95 (1974).

The economic literature commonly argues that most individuals exhibit decreasing absolute risk aversion, that is, they become more willing to accept small bets of fixed odds as wealth increases (id. at 96). For the quadratic, however, the coefficient of absolute risk aversion is $2 b /(a-2 b w)$, which increases with $w$ over the range in which the marginal utility of wealth is positive (the range over which the quadratic is a plausible approximation of utility). This observation provides a further objection to the proposition that the quadratic provides a reasonable approximation of utility for risk-averse individuals.

39 The appendix, section 5 , provides an illustration. 
relative to the expectation damages rule. It also alters the shape of the distribution to an extent that some risk averters may find disadvantageous. But if the variance of returns is an adequate measure of risk for the producer, a debatable proposition, it follows that $B=V$ is the optimum in the simplified formulation of the second-best problem. ${ }^{40}$ And, in the general formulation, the assumption that "risk" is adequately captured by variance also generates an optimum at $B=V$ in many cases. But it is impossible to rule out the possibility that the optimum for the general formulation may lie between $V$ and $K$, or that it may lie below $V$.

c) Risk-averse Producer and Buyer. If the buyer is also risk averse, the impracticability defense is less advantageous (or more disadvantageous) relative to the expectation damages rule. The reason is quite simple-the expectation damages rule provides the buyer with a return of $V-r$ with certainty, while the impracticability defense places risk on the buyer because the benefits of performance are lost if the realization of $c$ is large enough. Thus, for any choice of $B<K$, the contract price, $r$, must fall relative to its value under the expectation damages rule by more than enough to offset the reduction in the expected wealth of the buyer-the buyer will require a risk premium to maintain his expected utility. For this reason, the reduction in $r$ under any version of the impracticability defense is greater with a risk-averse buyer than a risk-neutral buyer, and, ex ante, the impracticability defense is less advantageous to the producer.

In general, the second-best optimum will depend on the precise utility functions of the producer and the buyer, the probability distribution of $c$, the outside wealth of the parties, and the division of contractual surplus between them. It is not possible to devise simple guidelines for choosing $B$, other than to say that the more risk averse the buyer, the greater the risk premium that the buyer will require under the impracticability defense, and thus the less attractive the impracticability defense becomes to the contracting parties.

More useful results can be developed if the uncertainty facing the contracting parties has a simpler structure. As an illustration, suppose that the producer and buyer are identical in every respect: $u(\cdot) \equiv v(\cdot)$, and $m=y$. Suppose further that the cost of performance, $c$, can take only two possible values: $c_{1}<V$, and $c_{2}>V$. Finally, suppose that the bargaining process leads the producer and buyer to divide the surplus from performance between themselves equally when $c=c_{1}$, so that $V-r=r-c_{1}$. Then, discharge of the producer's obligation to perform in the event that

${ }^{40}$ As the analysis of the case law in Section II will indicate, however, the impracticability defense is generally much more stringent-rarely will the producer be able to invoke the defense successfully when performance is just barely inefficient. 
$c=c_{2}$ is not merely second-best optimal, but first-best optimal. ${ }^{41} \mathrm{~A}$ choice of $B=V$ in the simplified formulation of the second-best problem, or any choice of $B$ above $c_{1}$ and below $c_{2}$ in the general formulation, will achieve this first-best optimum.

This simple example illustrates how a rule of discharge may mimic a rule of 50-50 loss splitting-when the surplus from performance is evenly divided between the parties in all states of the world in which performance will occur, discharge in other states of the world has the effect of evenly dividing the losses. Such a division of the loss is efficient in a contract between identical, risk-averse parties. But if this observation is to serve as a justification for discharge in practice, courts must be able to determine that the parties are roughly identical in their attitudes toward risk and must also be able to observe how expected surplus was divided ex ante. The ability of the courts to do so may certainly be questioned. Further, this justification for discharge applies only to cases in which the uncertainty facing contracting parties has a particular, simple structure that allows the fixed-price contract to divide surplus equally for all states of the world in which performance is efficient. Such cases will be fairly uncommon.

$$
* * *
$$

The analysis to this point suggests how the impracticability defense may, in theory, provide a second-best risk-sharing device in some cases. ${ }^{42}$ But it also raises doubts about the usefulness of the impracticability defense for that purpose in practice. Even assuming that courts can make

\footnotetext{
41 This proposition follows from the condition for first-best risk sharing noted earlier-the marginal rates of substitution between dollars in the two states of nature must be equal for the producer and the buyer. See sources cited note 14 supra. Intuitively, the requirement that the marginal rates of substitution be equalized may be understood with reference to the "contract curve" in an Edgeworth Box. Optimal risk sharing involves an exchange of claims on wealth contingent on the future state of nature. This exchange of claims between the producer and the buyer should proceed until they attain a point on the contract curve, defined by tangency of their indifference curves (equality of marginal rates of substitution). For an exposition, see Jack Hirshleifer \& John Riley, The Analytics of Uncertainty and Information-an Expository Survey, 17 J. Econ. Lit. 1375, 1385 (1979).

Thus, let $d$ equal the first-best value of damages in the event of nonperformance when $c=c_{2}$. The condition for first-best risk sharing implies that

$$
u\left(y+r-c_{1}\right) / u(y-d)=v(m+V-r) / v(m+d) .
$$

Under the assumptions that $u \equiv v, y=m$, and $V-r=r-c_{1}$, this condition holds if and only if $d=0$.

42 Note that the analysis has omitted any consideration of the possibility that the producer or the buyer might be a risk preferrer-the implicit assumption is that such cases are empirically unimportant.
} 
accurate qualitative judgments about the existence of risk neutrality or risk aversion on the part of contracting parties, such judgments do not in general suffice for a reliable identification of cases in which discharge of the obligation to perform is more efficient than adherence to the expectation damages rule. Discharge is plainly not optimal if the producer is risk neutral, but if the producer is risk averse, a discharge of the obligation to perform may or may not improve the efficiency of risk allocation. The optimality of discharge is especially difficult to assess if both parties are risk averse. The efficiency of discharge, and the efficient threshold of discharge (efficient value of $B$ ), depend on the utility functions of the contracting parties, their wealth levels, and the probability distribution of the underlying random variables - factors that are generally unknown and quite possibly unknowable to the courts.

\section{B. Reliance and Mitigation of Damages}

The expectation damages rule provides the benefits of performance to the buyer with certainty, notwithstanding the fact that performance may prove inefficient ex post. As a consequence, buyers may lack the proper incentive to limit reliance investments ex ante and may lack the proper incentive for mitigation of damages ex post. The impracticability defense may in theory help to relieve both problems.

\section{Reliance}

It is well known that buyers may tend to overinvest in reliance measures with the expectation damages rule in force $\mathrm{e}^{43}$ - the buyer perceives a private benefit from the reliance investment whether or not performance occurs, yet the investment has no social value if the contemplated performance becomes inefficient. If the parties anticipate this problem, they may write an express contractual provision requiring the buyer to invest only in Pareto-efficient measures. But if transaction costs prevent the negotiation or enforcement of such a provision, overinvestment in reliance may indeed occur under the expectation damages rule.

The impracticability defense will likely result in lower reliance expenditures because the buyer no longer perceives the benefits of performance to be certain. This observation arguably - with the other side of the argument to follow in a moment-provides a justification for the impracticability defense in some cases.

To illustrate, assume that both the buyer and the producer are risk neutral. Imagine that the buyer makes expenditures of $e$ on reliance mea-

${ }^{43}$ See Shavell, supra note 8; Rogerson, supra note 8. 
sures, and that the value of performance to the buyer is $V(e)$. Assume that $V(e)$ is increasing and strictly concave (diminishing returns to reliance expenditures). ${ }^{44}$ Let $e^{*}$ equal the Pareto-efficient level of reliance under a first-best contract.

One way to induce the buyer to invest efficiently in reliance is to modify the expectation damages rule to set expectation damages equal to $V\left(e^{*}\right)-r$, whatever the actual level of reliance. ${ }^{45}$ Equivalently, the conventional expectation damages rule (damages equal to $V(e)-r$ ) might be modified to bar recovery if reliance expenditures exceed $e^{*}$. Again, the buyer will then perceive no benefits from overinvestment and will invest efficiently.

Yet a third way to ameliorate overinvestment in reliance is through the impracticability defense. ${ }^{46}$ It is not difficult to show ${ }^{47}$ that, with both parties risk neutral and conventional expectation damages equal to $V(e)$ $-r$ if the obligation to perform is not discharged, the optimal value of $B$ in the general formulation of the second-best problem is $B=V\left(e^{*}\right)$. It follows immediately that $B=V\left(e^{*}\right)$ is also the solution to the simplified formulation. Indeed, such a choice of $B$ is not second best, but first bestit allows risk-neutral parties to attain the level of welfare that they would attain in a world of zero transaction costs.

The intuition is quite clear: as long as $B \geq V\left(e^{*}\right)$, the producer has no incentive for inefficient breach. But any choice of $B>V\left(e^{*}\right)$, coupled with an award of conventional expectation damages $V(e)-r$ if $c \leq B$, provides the buyer with the benefits of performance for states of the world (realizations of $c$ ) in which performance is inefficient and, thus, induces overinvestment in reliance. A choice of $B=V\left(e^{*}\right)$, by contrast, confronts the buyer with the prospect of losing the benefits of performance in precisely the states of the world in which performance is inefficient, thus inducing the buyer to choose $e^{*}$, notwithstanding the inability of the producer to write an enforceable contract to require that level of expenditure. $^{48}$

${ }^{44}$ This model of reliance expenditure is slightly simplified from the model employed in Shavell, supra note 8.

${ }^{45}$ See Robert Cooter \& Robert Ulen, Law and Economics 309-16 (1988).

46 The analysis here remains confined to a choice between expectation damages $(B=K)$ and the impracticability defense $(B<K)$. Consideration of reliance damages is omitted on the premise that reliance damages are likely Pareto inferior to expectation damages. See Shavell, supra note 8.

${ }^{47}$ See the appendix, section 6.

${ }^{48}$ Note that the existence of opportunities for reliance investments weighs against choices of $B<V\left(e^{*}\right)$. As noted, circumstances may arise in which the optimum in the general formulation lies below $V\left(e^{*}\right)$, notwithstanding the danger of inefficient breach or the need for costly renegotiation-conceivably, the benefits of risk sharing at that threshold of 
The presence of risk aversion complicates the analysis, but the prospect of overinvestment in reliance under the conventional expectation damages rule still tends to weigh against a choice of $B=K$ and in favor of a lower threshold of discharge in the general formulation of the secondbest problem. As noted earlier, for example, if the producer is risk neutral and the buyer risk averse, $B=K$ is uniquely optimal in the absence of opportunities for reliance. But once the possibility of reliance is introduced, a trade-off arises between the inefficiency of reliance expenditures when $B=K$ and the inefficiency of risk sharing when $B<K$. Quite conceivably, the optimum in the general formulation may lie below $K$, and the optimum in the simplified formulation may lie at $B=V\left(e^{*}\right)$. Because of risk aversion, however, such optima are truly second best.

This last observation suggests one objection to the proposition that an impracticability defense might be used to reduce the inefficiency of investments in reliance: if the courts can accurately determine $e^{*}$, which they must if $B$ is to depend on $e^{*}$, then the impracticability defense is not in general a first-best solution to the problem of overinvestment in reliance-an alternative rule that pays the buyer ordinary expectation damages, but only if he invests no more than $e^{*}$, can often do better, as can a modified expectation damages rule that sets damages equal to $V\left(e^{*}\right)-r$.

Yet, perhaps the courts lack the ability to ascertain $e^{*}$ with confidence. They will then be unable to condition expectation damages on $e^{*}$, and the impracticability defense arguably has some appeal as a second-best solution to the problem of overinvestment in reliance. For example, suppose again that both parties are risk neutral. Because $e^{*}$ is unobservable, the court sets $B=\hat{B}$, where $\hat{B}<K$, and $\hat{B}$ is large enough that inefficient breach will not result..$^{49}$ It is easy to show that such a choice of $\hat{B}$ induces a more efficient (lower) investment in reliance than the expectation damages rule, and is thus Pareto superior. ${ }^{50}$

This rationale for the impracticability defense is certainly open to question. It relies on an assumption that courts have considerable difficulty determining the efficient level of reliance and are thus unable to adopt superior rules to control overinvestment in reliance. Yet, if the courts lack the ability to ascertain the efficient level of reliance, they will have

discharge may dominate. But a choice of $B<V\left(e^{*}\right)$ also tends to induce underinvestment in reliance because in some states of the world (realizations of $c$ that exceed $B$ but do not exceed $V\left(e^{*}\right)$ ) performance is efficient but the buyer either loses the benefits of performance or must expend resources on renegotiation to secure it.

49 Precisely what is meant by "inefficient breach" here is rather subtle since the court must operate in a second-best world. See the appendix, section 6.

${ }^{\text {so }}$ Id. 
great difficulty weighing the benefits of more efficient reliance against any costs that may arise if the producer is excused from his promise to perform (such as the cost of shifting risk to a risk-averse buyer or the adverse effect of discharge on certain incentives of the producer, to be discussed below). ${ }^{51}$

Moreover, this rationale for the defense rests not on any notion that performance has become "impracticable" for the producer but simply on the observation that the conventional expectation damages rule tends to induce overinvestment in reliance. Thus, it applies in theory to many cases in which performance is not especially burdensome to the promisor. Plainly, therefore, it will not supply a positive theory of the impracticability defense.

\section{Mitigation of Damages}

The analysis to this point assumes that the buyer has no alternative suppliers who, in the event of a breach by the producer, can provide the good or service in question (or a reasonable substitute) at a price below what the buyer is willing to pay. More generally, it denies that the buyer has any opportunities to mitigate damages in the event of a breach by the producer. Opportunities to mitigate often arise.

But under an inflexible expectation damages rule that awarded the full expectation interest regardless of the buyer's behavior, the buyer would lack the incentive to search for an adequate, alternative source of supply. Search is costly, and the buyer would gain nothing from the expenditure of these costs if the expectation damages rule fully "insured" him against losing the expected benefits of performance. By contrast, if the obligations of the producer were discharged under the impracticability defense, the moral hazard created by the expectation damages rule would disappear. The buyer would then internalize the costs and benefits of efforts to secure alternative supplies (and other feasible opportunities to mitigate damages) and thus have an incentive to mitigate efficiently.

At first blush, this analysis might seem to justify a discharge of the producer's obligation to perform-and thus to justify the impracticability defense-under certain conditions. ${ }^{52}$ Specifically, classes of cases may exist where discharge is not objectionable on risk-sharing grounds, and does not unduly affect the incentives of the producer, ${ }^{53}$ yet provides a valuable incentive for the buyer to mitigate damages.

${ }^{51}$ See Section IC below.

52 See Bruce, supra note 5, at 316.

${ }^{53}$ See Section IC below. 
The flaw in this argument, of course, is that a discharge of the performance obligation is unnecessary to create the proper incentive for efficient mitigation of damages. Rather, all that is required is a modification of the expectation damages rule to incorporate a requirement for efficient mitigation. Indeed, both the U.C.C. and the common law embody such a requirement. ${ }^{54}$

A recent article by Goldberg, ${ }^{55}$ however, contends that discharge is sometimes justified as a means to induce efficient mitigation because the mitigation of damages requirement in the law is difficult to administer. That is, Goldberg suggests that courts are imperfect monitors of the efficiency of mitigation, which creates a moral hazard problem that allows buyers to mitigate less than efficiently without penalty. ${ }^{56}$ Thus, the argument runs, in cases where the ex ante inefficiencies of a prospect of discharge are low and the ex ante value of efficient mitigation is high, discharge is the best option.

According to Goldberg, the ex ante costs of a prospect of discharge will be low when the event that renders performance impracticable is "uncorrelated with market conditions" ${ }^{\prime 57}$-that is, when the expected future price of substitutes for whatever the producer is to supply, conditional on the event that renders performance impracticable, is approximately equal to the current price of substitutes. An example might be the occurrence of a fire in the factory of a single producer that greatly increases costs for that producer but does not have much effect on the market price of similar products because the producer is small in relation to the market as a whole.

In fact, Goldberg is too restrictive in his specification of the conditions under which discharge might be appropriate. To be sure, when the event that renders performance impracticable is "uncorrelated with market conditions," as Goldberg defines that phrase, the prospect of discharge may impose relatively little expected cost on the buyer ex ante. But where incentives to mitigate are important, the parties may be equally advantaged by a prospect of discharge even when the contingency that makes performance impracticable is highly correlated with market conditions, and thus the prospect of discharge imposes considerable expected cost on the buyer. ${ }^{58} \mathrm{~A}$ risk-neutral buyer can be fully compensated through an

54 See, for example, Calamari \& Perillo, supra note 1, at 538-43; U.C.C. § 2-713.

55 See Goldberg, Impossibility, supra note 5 . The argument is also nicely exposited in Douglas Baird, Long-Term Contracts and Commercial Impracticability (unpublished manuscript, University of Chicago, 1989).

56 A similar argument is developed in Epstein, supra note 21.

57 Goldberg, Impossibility, supra note 5.

58 Suppose, for example, that the increase in the cost of performance may affect all sellers in the market to greater or lesser degree. Consequently, in the event of a cost increase for a 
adjustment in the price, and the parties will reap joint gains from more efficient mitigation.

This justification for the impracticability defense has some initial appeal if one accepts the premise that courts do a poor job at assessing the efficiency of mitigation. Yet, one must further imagine that courts are relatively better at identifying the cases (or, more precisely, the contingencies) for which a prospect of discharge imposes less cost on the parties ex ante than the benefits ex ante of more efficient mitigation, a troublesome proposition.

The very existence of the contract may suggest that the buyer is risk averse and seeks protection from price volatility in the spot market. If so, the prospect of discharge under any contingency-whether or not "uncorrelated with market conditions"- - will impose an efficiency cost on the parties $^{59}$ by creating risk for the buyer in a contract that was entered in part for the purpose of allowing the buyer to lay off risk. ${ }^{60}$ Alternatively, just as courts may be imperfect monitors of the efficiency of mitigation, so may they be imperfect monitors of the extent to which the prospect of a discharge may cause the seller to behave inefficiently. Perhaps the seller will breach when performance is efficient, or take inadequate precautions to guard against the event that renders performance impracticable, ${ }^{61}$ or fail to lay off the risk of cost increase on a superior risk bearer, ${ }^{62}$ or fail to make an efficient disclosure to the consumer of the probability of nonperformance. ${ }^{63}$

For these reasons, the prospect of a discharge will generally impose some efficiency costs on the parties to the contract. These costs must be weighed against the benefits of more efficient mitigation to determine the contingencies under which discharge will be efficient. ${ }^{64}$ Yet, if the courts

particular producer, the price of substitutes is likely to rise as well. The producer and the buyer may still prefer discharge in the event of a cost increase if the beneficial effect on incentives to mitigate is great enough and any adverse effect of the prospect of discharge on risk sharing and the seller's incentives is small enough.

59 To be sure, if the probability of the contingency that triggers discharge is very low, the efficiency costs attributable to the introduction of risk may be small. But then the expected gains from more efficient mitigation in the event of discharge will be small as well.

${ }^{60}$ To put the point slightly more formally, even granting the assumption that the expected value of future spot prices is independent of the event that makes performance impracticable, a risk-averse buyer does not care simply about the expected value of future prices. Rather, such a buyer cares also about the volatility of prices and may enter the contract to lay off the risk that future prices may exceed their ex ante expected value. Discharge of the producer's obligations shifts this risk back to the buyer.

61 See Section IC3 below.

62 See Section IC1 below.

63 See Section IC2 below.

64 A further possible objection to discharge as a device for inducing efficient mitigation is that it is not necessary. The court could substitute any constant measure of damages (that is, 
are presumed unable to identify the efficient mitigation strategy, how can they divine an estimate of the benefits of more efficient mitigation subsequent to discharge? And if they cannot, how can they possibly weigh those benefits against the costs associated with the possibility of discharge? ${ }^{65}$

To be sure, if a court can identify with confidence cases where the buyer is approximately risk neutral, where the court can police the seller's behavior fairly well, and where the court cannot police the buyer's mitigation behavior, then Goldberg's analysis would suffice to justify discharge. It is by no means obvious, however, why courts should view themselves as so expert at certain difficult tasks, yet so inept at another. And, as the discussion in Section II will suggest, Goldberg's analysis does not provide a convincing explanation for the impracticability doctrine in practice. ${ }^{66}$

\section{Further Considerations}

The analysis to this point omits a number of important factors that bear on the ex ante efficiency of an impracticability defense in many contractual settings. These factors include the availability of insurance and opportunities for hedging, asymmetric information, various moral hazards, and litigation costs. Most of these factors are discussed elsewhere in the literature on the impossibility doctrine, and hence the remarks to follow are quite brief. But they do indicate how each factor may affect the second-best optimum. On balance, most of these factors generally weigh in favor of the expectation damages rule.

\section{Insurance and Hedging}

The analysis to this point assumes that the producer cannot purchase "insurance" against fluctuations in the cost of production. This assumption may well be incorrect, for the producer may have a variety of opportunities to lay off the risk of cost fluctuations on a superior risk bearer.

\footnotetext{
damages equal to some fixed amount not a function of the buyer's efforts to mitigate) and thereby provide equivalent incentives to mitigate while still providing the buyer with some positive level of damages.

65 This analysis closely parallels the discussion of the impracticability defense as a way to reduce overinvestment in reliance. That is not surprising, as the problem of overinvestment in reliance ex ante is closely related to the problem of underinvestment in mitigation ex post. Both arise from the fact that an unmodified expectation damages rule allows the buyer to externalize certain costs and benefits of his decisions.

66 The need for greater incentives to mitigate is more appealing as an explanation for certain force majeure clauses. See Goldberg, Impossibility, supra note 5, at 115.
} 
Suppose, for example, that the uncertainty arises because a fire may destroy the producer's raw material supply, necessitating replacement at a higher cost. A conventional fire insurance policy might shift the risk efficiently. Perhaps more commonly, uncertainty about production costs will arise because of prospective fluctuations in the spot prices of necessary inputs. For some inputs, a risk-averse producer may be able to avoid these risks by purchasing the inputs in the futures market.

To the degree that the producer can lay off the risk of cost increases in the insurance or futures markets, it is most unlikely that the ex ante welfare of the contracting parties can be enhanced by allowing the producer to shift risk to the buyer through the impracticability defense ${ }^{67}$ The impracticability defense in such cases can only weaken the incentive of the producer to purchase insurance or futures contracts and, thus, in many cases leads to an inferior risk allocation. It follows that the expectation damages rule is almost certainly the second-best optimum when cost fluctuations for the producer are attributable to insurable events or to fluctuations in the prices of inputs that are sold in futures markets. ${ }^{68}$

By contrast, the buyer will rarely have attractive opportunities to lay off the risk of nonperformance by the producer in an insurance or futures market. Conventional "insurance" to cover damages from breach of contract is generally unavailable, undoubtedly because of moral hazard and transaction cost considerations. ${ }^{69}$ Likewise, even when futures markets exist for the goods or services that the buyer wishes to purchase, a futures contract that obligates the buyer to take delivery only in the event of nonperformance by another seller would hardly resemble the usual futures agreement.

${ }^{67}$ Insurance companies are superior risk bearers, of course, by virtue of their ability to diversify risk through holdings of uncorrelated risky claims. Futures market participants are superior risk bearers for other reasons. Often, they seek to avoid the risk of downward fuctuations in the prices of their products and will sell those products forward at a price equal to or below the expected future spot price-hence, they offer the producer an opportunity to contract for future supplies at a fixed, actuarially attractive price. Still other participants in futures markets are simply gamblers with little or no aversion to risk. On the informational and risk distribution functions of futures markets, see Sanford Grossman, The Existence of Futures Markets: Noisy Rational Expectations and Informational Externalities, 44 Rev. Econ. Stud. 431 (1977).

68 See Posner \& Rosenfield, supra note 4, at 90-92; Joskow, supra note 5, at 153; Bruce, supra note 5, at 321-22.

69 For example, it would be inefficient for insurance companies to insure the buyer against an inefficient breach by the producer-the welfare of all parties could be improved if the producer could be required to perform. But insurance limited to cases of efficient breach would be extraordinarily difficult to administer, as the question whether a particular breach was efficient or inefficient would depend in part on the producer's cost of production, a datum often known only to the producer. 


\section{Asymmetric Information}

Quite plausibly, circumstances may arise in which one party to a contract has better information at the time of contracting about future contingencies that may increase the cost of performance. Such cases are characterized by asymmetric information about those contingencies.

A number of arguments have been made for placing the risks associated with various contingencies on the party with superior information about them. ${ }^{70}$ Suppose that a contingency is avoidable, or its severity reducible, through costly precautions. The party with superior information is more likely to recognize the opportunity for these precautions and can better conduct a cost-benefit analysis to determine their efficient level. Likewise, if the adverse consequences associated with a particular contingency are insurable, the party with the superior information is more likely to recognize the possible benefits of insurance and to search the market for favorable policies. Finally, even if the contingency is neither avoidable nor insurable, the party with superior information can better evaluate the significance of the contingency and make a judgment whether the expected costs associated with the contingency are so great that the contract is not worth entering. Thus, the existence of asymmetric information about a given contingency will, in many cases, weigh in favor of placing the risk of that contingency on the better-informed party.

This proposition is strengthened by noting that an allocation of risk to the better-informed party may induce disclosure and thus eliminate asymmetric information. Consider again the contract between the producer and the buyer, and imagine a contingency that will dramatically increase the cost of production for the producer to the point that performance is no longer worthwhile. The probability of the contingency is $p$. Assume that, putting information considerations to one side, a second-best impracticability defense would discharge the producer's obligation to perform in the event that the contingency materializes. But suppose further that only the producer knows the true value of $p$ and that the buyer is ignorant of the contingency in question (that is, he believes that $p=0$ ). As noted, various inefficiencies may then arise. The buyer may enter the contract even if the "true" expected surplus from the contract is negative-that is, when the buyer's true willingness to pay, conditioned on the correct value of $p$ and on the existence of a second-best impracticability defense, would fall short of the producer's reservation price for entering the contract. Alternatively, the buyer may forgo cost-effective advance measures to mitigate the prospective losses from nonperformance that he would take if

${ }^{70}$ See Posner \& Rosenfield, supra note 4, at 90-97. 
he knew the true probability of the contingency at issue, or he may engage in excessive reliance. These inefficiencies would be avoided or at least reduced if the producer could be induced to disclose $p$ to the buyer.

An unconditional discharge of the producer's obligations in the event of the cost increase provides no incentive for disclosure. As long as the buyer remains ignorant of the contingency at issue, he erroneously anticipates that he will receive the benefits of performance with certainty, and his willingness to pay to enter the contract is accordingly inflated. This circumstance is likely advantageous to the producer, and hence the producer has no interest in supplying information to the buyer. ${ }^{71}$

Consider, therefore, a conditional rule under which discharge is precluded and the producer is required to pay expectation damages unless the producer discloses the value of $p$ to the buyer. The buyer loses nothing if he remains ignorant of $p$-damages fully compensate him if the contingency occurs. Because discharge is by hypothesis Pareto superior to expectation damages, the producer can improve on this situation by disclosing $p$ to the buyer and gaining the protection of the impracticability defense. This proposition presupposes, of course, that disclosure does not itself entail an expenditure of resources so large as to make it unprofitable. But, if $p$ is disclosed accurately, the buyer will have greater incentive to take cost-effective measures to reduce the prospective losses from nonperformance and to limit reliance, and he will not enter the contract unless the expected surplus is positive. ${ }^{72}$

One issue remains to be considered-whether the producer can, without accurate disclosure of $p$, induce the buyer to enter a contract that would expressly discharge the producer's obligation to perform should the contingency materialize. ${ }^{73}$ The answer is-perhaps. The producer probably cannot initiate negotiations regarding an express discharge provision without revealing the fact that $p>0$. He can nonetheless attempt to mislead the buyer into underestimating the true value of $p$ and, if he is successful, the same sorts of inefficiencies may arise as when the buyer mistakenly believes that $p=0 .{ }^{74}$

71 The producer will not benefit, of course, if competition prevents him from appropriating any of the increment in the buyer's willingness to pay.

72 For an instructive discussion of how difficult it is to craft a legal rule that will optimize simultaneously the disclosure decision by the producer, the performance or breach decision by the seller, and the reliance decision by the buyer, see Richard Craswell, Performance, Reliance, and One-sided Information, 18 J. Legal Stud. 365 (1989).

${ }^{73}$ See Bruce, supra note 5, at 318-19.

74 Of course, the law does not place constraints on the ability of the producer to mislead the buyer. The provision of false or misleading information or, in some cases, the failure to disclose certain material information may result in civil or even criminal liability. See Calamari \& Perillo, supra note 1 , at 287-92. 
Yet, in all likelihood, some disclosure is better than none. If the buyer remains totally ignorant that $p>0$, his willingness to pay is more inflated, and his steps to mitigate potential losses are more inadequate than if he merely underestimates $p$ but assumes it to be positive. Furthermore, if the buyer has been misled about $p$, he may be able to seek redress in an action for misrepresentation, and this possibility may deter the producer from attempting to mislead the buyer. Finally, the disclosure that $p>0$ may lead the buyer to conduct his own investigation of $p$ that may considerably improve the quality of his information. Thus, any rule that encourages the producer to disclose that $p>0$ may do much to alleviate the potential inefficiencies associated with asymmetric information, even if fully accurate disclosure is not forthcoming.

This analysis, applied to cases in which the producer's cost of performance has increased, suggests the following principles. First, to the extent that courts can accurately determine whether information was asymmetric ex ante, it may well be efficient to refuse to discharge the producer's obligation to perform, even assuming that discharge would otherwise be efficient, if the buyer was uninformed about the contingency that made performance impracticable. Such a conditional rule encourages disclosure and places the risk of cost increases on the better-informed party in the absence of disclosure.

Second, in cases where the courts cannot accurately determine whether information was asymmetric ex ante, it seems reasonable to presume that the producer is the better-informed party more often than the buyertypically, the producer will have better information about the contingencies that affect his own costs of performance. The possibility of asymmetric information then weighs in favor of the expectation damages rule or, at least, in favor of a higher threshold for discharge (a higher value of $B$ in the model above) to encourage greater disclosure and to reduce the inefficiencies that result when the buyer is uninformed.

\section{Moral Hazard and the Cost of Performance}

As noted above, the producer may have the ability to take precautions against increases in the cost of performance. One such precaution-the purchase of an insurance or futures contract-has already been discussed. More generally, the producer may have the opportunity to invest in technology, in spare capacity, or in other measures that, in the event of certain contingencies, restrain any increase in the cost of performance. ${ }^{75}$

${ }^{75}$ See Posner \& Rosenfield, supra note 4, at 90; Joskow, supra note 5, at 154-55. 
The impracticability defense may create a serious moral hazard problem when the producer has opportunities to invest in such measures. In particular, assume that some positive level of investment is Pareto efficient for the contracting parties but that transaction costs prevent the producer and the buyer from writing and enforcing a contract to require that level of investment by the producer. Perhaps the buyer lacks the information to ascertain the efficient investment or the ability to observe whether the producer has undertaken that investment. In any event, because the buyer cannot contract effectively for efficient investment by the producer, the producer will invest at a level that maximizes his own welfare without regard to the welfare of the buyer.

Under the expectation damages rule, the producer has an incentive to make the efficient investment even though the buyer cannot monitor such investments. Because the buyer receives the expected benefit from performance with certainty, the producer fully internalizes the benefits of measures to restrain increases in the cost of performance and will invest in them efficiently.

Under the impracticability defense, by contrast, measures to restrain cost increases reduce the likelihood of discharge and thus have the effect of increasing the threshold of discharge from the producer's perspective. This effect is disadvantageous to the producer, who must either pay expectation damages or perform at a loss when his cost of performance approaches the threshold of discharge. As a consequence, the producer will tend to underinvest in measures to avoid cost increases under the impracticability defense.

This phenomenon may be illustrated with a slight variant of the model developed above. Suppose that the producer's cost of production, $c$, is given by $c=z-\gamma(I)$, where $z$ is a random variable, $I$ is a monetary investment in cost-reduction measures by the producer (made before uncertainty about $z$ is resolved), and $\gamma(I)$ is the amount of the resulting cost reduction $\left(\gamma^{\prime}>0 ; \gamma^{\prime \prime}<0\right)$. Under the impracticability defense, the contract is discharged when $c>B$, which implies $z>B+\gamma(I)$. This last inequality reflects the influence of cost-reduction measures on the threshold of discharge as perceived by the producer-the greater the investment $I$, the higher the value of $z$ that is required before the contract will be discharged. This effect of $I$ on the threshold of discharge is disadvantageous to the producer at the margin because the contract is invariably unprofitable to the producer when $z$ is so large that the threshold of discharge is approached. But this private detriment to the producer is not a social detriment because the buyer gains when the threshold of discharge increases. For this reason, the producer perceives a return to 
investments in cost-reduction measures that is below the social return, and he will underinvest in them.

This problem warrants one of two possible responses by the courts, depending on the ability of the courts to ascertain the efficient level of investment by the producer. One possibility is that the courts are no better suited than the buyer to monitor the efficiency of the producer's investments. If so, then the existence of opportunities for investments to avert cost increases weighs in favor of the expectation damages rule or, at least, in favor of a higher threshold for discharge (a higher value of $B$ ). The higher the threshold of discharge, the more the producer will internalize the risk of cost increases, and the greater the extent to which his investments in measures to avoid them will approach the efficient level. ${ }^{76}$

Alternatively, if the courts can determine with reasonable accuracy whether the producer has undertaken the efficient investment, then no modification of the otherwise efficient threshold for discharge is warranted. But discharge should be conditioned on a determination that the producer made the efficient investment. Such a rule, like the expectation damages rule, leads the producer to internalize fully the benefits of investments to avert cost increases and will thus encourage him to undertake all efficient investments. ${ }^{77}$

\section{Costs of Adjudication and the Predictability of Legal Rules}

An efficient choice among alternative legal rules must attend to the possibility that some rules are cheaper to administer than others, requiring fewer resources on the part of litigants and the judicial system. In addition, if the maximization of ex ante welfare is to guide a choice among alternative rules of contract law, it is important that the chosen rule be sufficiently clear and predictable that contracting parties can forecast with reasonable accuracy how it will apply. A legal rule that is vague and

\footnotetext{
76 This proposition is analogous to a fundamental result in the economic theory of agency - when agents are risk averse, and principals are limited in their capacity to monitor agents' behavior, a tension exists between optimal risk sharing between the principal and agent and the creation of optimal incentives for the agent. The Pareto-efficient solution to this problem, in most cases, is to compromise risk sharing and incentives by leaving somewhat more risk on the agent than would be optimal in the absence of the moral hazard problem. See, for example, Sanford Grossman \& Oliver Hart, An Analysis of the PrincipalAgent Problem, 51 Econometrica 7 (1983); Stephen Ross, The Economic Theory of Agency: The Principal's Problem, 63 Am. Econ. Rev. 134 (Paps. and Procs. 1973). See also Steven Shavell, On Moral Hazard and Insurance, 93 Q. J. Econ. 541 (1979).

77 If the producer underinvests, he will be liable for expectation damages. Yet, a producer who is liable for expectation damages will not underinvest-the equilibrium level of investment must then be exactly the efficient level, as at that point some of the risk of cost fluctuations shifts to the buyer, and the producer will surely perceive a net loss from any further investment.
} 
unpredictable, by contrast, may simply introduce uncertainty into the contracting process and force the parties to expend resources to customize their agreements to avoid that uncertainty. ${ }^{78}$ Vague and unpredictable rules also introduce greater uncertainty into the dispute resolution process, which increases the likelihood that litigants will develop disparate expectations about the chances that each side will succeed. The development of incompatible expectations about the outcome of dispute resolution will tend to impede settlement and foster a greater investment of resources in litigation. ${ }^{79}$ The implications of these observations for the choice between expectation damages and the impracticability defense will be explored at some length in the discussion of the case law that follows.

\section{Analysis of the Case Law}

This section examines the case law, with emphasis on cases where the impracticability defense has been successfully invoked. Drawing on the analysis of Section I, the discussion will suggest that few of these decisions have a clear efficiency justification. The analysis further suggests that the understandable willingness of the courts always to respect express contractual allocations of risk makes it even more difficult for the defense to enhance ex ante welfare. And, viewed from the standpoint of ex post efficiency, the impracticability defense has little to recommend it.

\section{A. The Paradigm Case of Increased Cost}

\section{The Mineral Park Case}

A recurring issue at common law was whether a substantial increase in the cost of performance could make performance "impossible," even though the promisor remained physically capable of performing. ${ }^{80}$ For many years, the courts resisted the notion that mere increased cost of performance might constitute impossibility. ${ }^{81}$ But with time, the concept

${ }^{78}$ See Joskow, supra note 5, at 154.

${ }^{79}$ On the significance of disparate expectations in the decision to litigate or settle, see, for example, George Priest \& Benjamin Klein, The Selection of Disputes for Litigation, $13 \mathrm{~J}$. Legal Stud. 1 (1984); Geoffrey Miller, Some Agency Problems in Settlement, 16 J. Legal Stud. 189 (1987).

${ }^{80}$ The distinction between physical impossibility and increased cost of performance is in one sense only a matter of degree-impossibility arises when the cost of performance has increased to infinity.

81 To be sure, the courts sometimes found performance "impossible" by artful interpretation of the contract. For example, if a farmer contracted to sell 1,000 bushels of wheat to a processing company after the fall harvest, and his wheat crop was destroyed by a flood, performance was "impossible" if the contract was interpreted as an agreement to sell the 
of impossibility has broadened considerably, and the First Restatement of Contracts defined impossibility as "not only strict impossibility but impracticability because of extreme and unreasonable difficulty, expense, injury or loss involved." 82

The Uniform Commercial Code embraced this notion of impossibility, establishing in $\$ 2-615$ (a) an "impracticability" defense to delay or nondelivery by a seller under a contract for the sale of goods. According to the commentary on \& 2-615(a), "[i]ncreased cost alone does not excuse performance unless the rise in cost is due to some unforeseen contingency which alters the essential nature of the performance. . . . But a severe shortage of raw materials due to a contingency such as war, embargo, local crop failure, unforeseen shutdown of major sources of supply or the like, which either causes a marked increase in cost or altogether prevents the seller from securing supplies necessary to his performance, is within the contemplation of this section." 83 The Second Restatement of Contracts endorsed the approach of the U.C.C. and further suggests that increases in labor costs, raw material prices, or other costs of production "well beyond the normal range" may constitute impracticability. ${ }^{84}$

Perhaps the leading case on the point is Mineral Park Land Co. $v$. Howard $^{85}$ The defendants agreed to purchase their requirements of gravel from the plaintiff's land. Defendants bore the cost of excavating and removing the gravel and agreed to pay the plaintiff five cents per ton. After removing about half of the gravel necessary to meet their requirements, the defendants turned to other sources because the remaining gravel on plaintiff's land was below the water table. The court found that the cost per ton of excavating and removing gravel below the water table was ten to twelve times the usual cost per ton. ${ }^{86}$ It then found performance impracticable because the parties had not anticipated the insufficiency of the volume of gravel above the water table.

The decision in Mineral Park is open to various objections. First, the allocation of risk to the plaintiff has no ready justification. The plaintiff was a company that owned land adjacent to the construction project; the

farmer's own fall crop; but if the contract was simply an agreement to sell 1,000 bushels of wheat, the farmer could still perform by purchasing the wheat on the open market and reselling it to the processing company. The former construction of such contracts not infrequently served as a basis for their discharge. See, for example, Matousek v. Galligan, 104 Neb. 731,178 N.W. 510 (1920). See the discussion of these cases in Section IIB below.

${ }^{82}$ Restatement (First) of Contracts $\$ 454$ (1932).

${ }^{83}$ U.C.C. $\&$ 2-615, comment 4 (1972).

${ }^{84}$ Restatement (Second) of Contracts $\S 261$, comment d (1981).

${ }^{85} 172$ Cal. 289, 156 P. 458 (1916).

${ }^{86} 156 \mathrm{P}$. at 459. 
defendants operated a construction company. This information provides little reason to suppose, for example, that considerations of risk aversion might warrant allocating to the plaintiff the risk that its benefits from performance might be lost. ${ }^{87}$ Nor does the report of the case suggest any reason to suppose that discharge might have been justified by concerns about excessive reliance, inadequate mitigation of damages, or any of the other possible justifications for discharge considered previously.

Indeed, the impracticability defense as stated in cases such as Mineral Park pays no attention to such issues. The inquiry is limited to the question whether the seller's cost of performance has increased to such a burdensome level as to become impracticable. But as the analysis in Section I suggests, the efficiency of discharge assuredly does not turn solely on the magnitude of the cost increase and, indeed, may have very little to do with the magnitude of the increase.

A second troublesome aspect of the decision in Mineral Park is its ambiguity:

Although there was gravel on the land, it was so situated that the defendants could not take it by ordinary means, nor except at a prohibitive cost. To all fair intents then, it was impossible for defendants to take it. ... We do not mean to intimate that the defendants could excuse themselves by showing the existence of conditions which would make the performance of their obligation more expensive than they had anticipated, or which would entail a loss upon them. But, where the difference in cost is so great as here, and has the effect, as found, of making performance impracticable, the situation is not different from that of a total absence of earth and gravel. ${ }^{88}$

What does this passage mean? Seemingly, the court holds that cost increases alone do not make performance impracticable unless they are "so great" as to make performance impracticable. The court further suggests that the cost increase was "prohibitive" but provides no guidance as to what is meant by "prohibitive." A ten- to twelvefold increase in cost was enough for discharge in Mineral Park, and cases since have suggested that a doubling of cost is not enough, ${ }^{89}$ but the threshold for discharge remains highly uncertain. ${ }^{90}$

${ }^{87}$ Discharge of the defendants' obligations may by chance have generated an efficient split of the losses if both parties were risk averse, but such a justification for the decision is conjectural at best.

88156 P. at 460 .

${ }^{89}$ See Transatlantic Financing Corp. v. United States, 363 F. 2d 312 (D.C. Cir. 1966), at 319 , and cases cited therein at 319 n.14.

${ }^{90}$ In Hein v. Fox, 126 Mont. 514, 254 P.2d 1076 (1953), the defendant contracted to drill a well on the plaintiff's land. After drilling 250 feet, the casing for the well broke and the defendant had to begin anew. He drilled 350 feet for the second well until he encountered an 
The Restatements and the U.C.C. do little to clarify the scope of the impracticability defense after Mineral Park. As noted, the U.C.C. commentary contemplates "a rise in cost . . due to some unforeseen contingency which alters the essential nature of performance," such as "a severe shortage of raw materials" that causes a "marked increase in cost." 91 The First Restatement refers to "extreme and unreasonable difficulty, expense or loss, "92 while the Second Restatement finds impracticability when costs of production increase "well beyond the normal range. " ${ }^{93}$ None of these statements of the scope of the impracticability defense provides an intelligible "default option" to contracting parties. A seller who wishes to avoid liability for damages in the event of a cost increase that makes performance inefficient would be foolish to rely on the impracticability defense to provide such protection. A buyer who wishes the seller to "insure" him against losing the expected benefits of performance should performance become inefficient can only wonder how much "insurance" is provided under the impracticability defense.

The result, in many ways, is the worst of all possible worlds-whatever allocation of risk the parties find mutually advantageous, they would be well advised to reduce it to writing, as it is anybody's guess how the law will resolve disputes under many contingencies. The expectation damages rule, by contrast, at least provides an understandable default allocation of risk, which will be acceptable to the contracting parties in many cases and will signal clearly to parties who prefer an alternative allocation of risk that they must bargain for it.

The vagueness and imprecision of the defense also tends to impede settlement and to invite a considerable investment of resources in litigation. Under the expectation damages rule, by contrast, it is at least much easier for litigants to predict whether the plaintiff will succeed in establishing the liability of the defendant. And, although the computation of expectation damages is not always straightforward, the existence of an impracticability defense by no means obviates the need for such computations-often, expectation damages must be computed anyway after claims of impracticability have been rejected.

impenetrable layer of rock. In the meantime, the Korean War erupted and the demands of the U.S. government for steel products created a shortage of steel casing for wells, to an extent that the defendant allegedly could not obtain the necessary casing for completion of the well. The court declined to find performance impracticable even under the facts as alleged by the defendant.

91 U.C.C. \& 2-615, comment 4 (1972).

92 Restatement (First) of Contracts $\$ 454$ (1932).

93 Restatement (Second) of Contracts $\$ 261$, comment d (1981). 


\section{The Florida Power Case}

The difficulties evident in the early decisions like Mineral Park have not been corrected with time. For example, Florida Power \& Light Co. v. Westinghouse Electric Corp ${ }^{94}$ involved a contract between Westinghouse and Florida Power for the sale of a nuclear reactor facility. Among other things, Westinghouse agreed to remove and dispose of spent reactor fuel. The accepted method for nuclear waste disposal at the time of contracting in 1966 was reprocessing, which involved the extraction of commercially valuable by-products from the spent fuel followed by storage of the remaining waste. ${ }^{95}$ No commercial facilities for reprocessing existed at the time of contracting, but plans for the construction of such facilities were under consideration. In the interim, the federal government announced that it would provide reprocessing services at government-owned facilities. After the contract was signed, however, mounting concern about the safety of reprocessing led to a number of lawsuits and other initiatives to halt its development. The emergence of a commercial reprocessing industry was thwarted, and the federal government eventually reneged on its commitment to supply reprocessing services. Thus, by the time that the nuclear facility purchased by Florida Power became operational, reprocessing was simply unavailable. Westinghouse then refused to honor its obligation to dispose of waste on grounds of commercial impracticability.

The court concluded that both Westinghouse and Florida Power, at the time of contracting, anticipated that Westinghouse would meet its obligations through reprocessing. Indeed, according to the court, Westinghouse anticipated a profit from reprocessing of about $\$ 20$ million. When reprocessing became unavailable, this anticipated profit was lost, and the eventual cost of alternative disposal methods was about $\$ 80$ million. In light of this $\$ 100$ million swing, the court found the obligation to dispose of the waste "impracticable.",96

It is difficult to fashion an efficiency justification for the decision in this case. ${ }^{97}$ Clearly, developments subsequent to the negotiation of the contract considerably increased the eventual cost of waste disposal. Even if the parties assigned negligible probability at the time of contracting to the collapse of the reprocessing industry, however, that fact alone provides no justification for placing the bulk of the attendant losses on Florida

94826 F.2d 239 (4th Cir. 1987).

95 Because of the value of the by-products, Westinghouse evidently agreed to dispose of the spent fuel at no charge to Florida Power. 826 F.2d at 241.

96826 F.2d at 277.

97 A thoughtful analysis of the Florida Power case may also be found in Baird, supra note 55. 
Power. ${ }^{98}$ Westinghouse is a large, publicly held corporation. Its shareholders have the ability to diversify their portfolios and, as a first approximation, the risks associated with events unique to the nuclear power industry appear to be unsystematic, or diversifiable, risks. The notion that risk aversion on the part of Westinghouse might justify the decision in Florida Power is therefore unappealing. ${ }^{99}$ Nor does the court identify any factors that might support a reliance or mitigation justification for the decision.

Furthermore, Westinghouse may have been in a superior position to develop or encourage the development of a substitute for reprocessing. ${ }^{100}$ The lower court, which rejected the impracticability defense, suggested that Westinghouse had forgone opportunities to encourage commercial interests to develop long-term storage facilities as an alternative to reprocessing and that Westinghouse might even have constructed its own storage facility. ${ }^{101}$ Thus, a familiar moral hazard issue arises with respect to the decision to discharge the contract. ${ }^{102}$

The case also suffers from much the same ambiguity as Mineral Park. The basis for the finding of impracticability was simply that a portion of the contract, the portion that required waste disposal, became highly unprofitable to the promisor. In relation to the contract as a whole, how-

98 As a result of the discharge, Westinghouse lost the anticipated \$20 million profit on reprocessing, and Florida Power lost the $\$ 80$ million cost of alternative waste disposal.

99 To be sure, the claim is sometimes made that publicly held corporations are risk averse. Some large corporations purchase commercial insurance against various risks, for example, and the hypothesis has been advanced that conglomerate mergers may be motivated by the desire of managers to reduce risk in their compensation package. See Yakov Ahimud \& Baruch Lev, Risk Reduction as a Managerial Motive for Conglomerate Mergers, 12 Bell J. Econ. 605 (1981). One explanation for risk-averse behavior on the part of corporations is that stockholders link managerial compensation to the profitability of the corporation to generate optimal performance incentives. See Alan Marcus, Risk Sharing and the Theory of the Firm, 13 Bell J. Econ. 369 (1982). Risk-averse behavior then arises as an agency cost that is better tolerated by shareholders than eliminated at the expense of managerial incentives. Even if correct, however, such analysis would not explain a decision to place most of the loss on Florida Power rather than Westinghouse.

100 Similarly, in Selland Pontiac-GMC v. King, 384 N.W.2d 490 (Minn. Ct. App. 1986), the promisor had agreed to construct school buses for the promisee, using bodies manufactured by a Canadian company. That company went into receivership and was unable to supply the bus bodies. The contract was then discharged, and the court did not inquire at all whether the promisor might have been better positioned to locate an alternative supplier for the bus bodies.

101826 F.2d at 256.

102 This analysis presupposes that other contracts between Westinghouse and various utilities required Westinghouse to provide waste disposal. Westinghouse would then have been in a better position than Florida Power to develop substitute waste disposal measures because Westinghouse would realize various economies of scale. 
ever, the increase in the cost of performance was significantly less than 50 percent of the contract price. ${ }^{103}$ This was nonetheless an "unreasonable and excessive cost" to Westinghouse in the view of the court. ${ }^{104}$ The court provides little guidance about what is meant generally by "excessive and unreasonable" and thus does little to aid other contracting parties in forecasting the application of the impracticability defense to various contingencies. Its value as a "default option" to contracting parties thus remains highly questionable. ${ }^{105}$

\section{The Waldinger Case}

Another troubling case is Waldinger Corp. v. CRS Group Engineers, Inc. ${ }^{106}$ The plaintiff was the successful bidder on a contract for the construction of a sewage treatment facility. In submitting its bid, the plaintiff had relied on a bid from the defendant subcontractor, who agreed to provide equipment to certain design specifications established by engineers for the sanitary district. The subcontractor knew at the time of bidding that its products could not meet those design specifications but believed that its products could meet the performance specifications for the requisite equipment. It further anticipated that the design specifications would be waived on showing that the performance specifications had been satisfied. This anticipation was purportedly based on common practice in the business, which was motivated in part by Environmental Protection Agency regulations that required "free and open" competition. Those regulations implicitly forbade the use of design specifications for the purpose of favoring particular contractors at the expense of others. ${ }^{107}$ But the engineers for the sanitary district refused to waive the design specifications, and the plaintiff was forced to purchase equipment from another subcontractor at a considerable premium over the defendant subcontractor's bid. The suspicion arose that the engineers had refused the waiver for impermissible reasons, as for the purpose of directing business to another company or out of animosity toward the defendant subcontractor, but the liability of the engineers for tortious interference

\footnotetext{
103826 F.2d at 277.

104 Id.

105 Transatlantic Financing, see note 74 supra, suggested that cost increases below 100 percent were insufficient to justify discharge. The court distinguished Transatlantic Financing by finding that the waste disposal obligation was, in effect, a separate contract from the contract for sale of the power plant, $826 \mathrm{~F} .2 \mathrm{~d}$ at 277 , and then concluded that the increase in the cost of waste disposal was well in excess of 100 percent.

106775 F.2d 781 (7th Cir. 1985).

${ }^{107}$ Id. at $785-86$.
} 
with contract had not been established. ${ }^{108}$ Nonetheless, the court found the obligations of the defendant subcontractor impracticable because the defendant could not have foreseen that the engineers would behave as they did in refusing to grant the waiver. ${ }^{109}$

The soundness of the decision is questionable, as nothing in the case suggests why the plaintiff was better suited than the defendant subcontractor to bear the risk that engineers for the sanitary district would find the subcontractor's equipment unsuitable. Indeed, a strong argument can be made to the contrary. The defendant subcontractor did not disclose to the plaintiff at the time of bidding that a waiver would be necessary for the defendant's equipment to be used on the project. Even if the defendant's expectation was that a waiver would be forthcoming with high probability, a waiver was obviously not a certainty. ${ }^{110}$ And, had the plaintiff known about the need for a waiver, it might have made a bid conditional on a waiver or simply raised its bid to compensate for the risk that a waiver might be denied. Either way, the contract might have been awarded to another company that could perform it more efficiently.

More generally, the decision in Waldinger encourages subcontractors to submit bids premised on certain assumptions about the contracting environment that may or may not prove correct. As long as the probability that those assumptions are correct is high enough ex ante to render their failure "unforeseeable," the subcontractor need not perform if some assumption proves incorrect and the subcontractor's cost of performance rises substantially as a consequence. ${ }^{111}$ This use of the impracticability defense does not merely allocate risks to the principal contractor for no apparent reason, but does so when the principal contractor may be entirely ignorant about them. The resulting distortion of the bidding process may be considerable.

${ }^{108}$ Id. at 791-92. If the engineers would ultimately be liable under a theory of tortious interference, then the availability of the impracticability defense to the subcontractor may have been of little consequence. The defendant engineers may ultimately have borne the entire loss, whether directly or through the equivalent of an indemnity action filed by the defendant subcontractor. But the defendant engineers may have been unable to satisfy judgments against them. Further, as noted, the liability of the engineers had not been conclusively established.

109 Id. at 786-89.

110 Indeed, by remanding the case for additional findings relating to the liability of the engineers, the court allows that denial of the waiver may not have been tortious but based on an exercise of reasonable discretion by the engineers.

111 In Waldinger, the defendant subcontractor was not disabled from performing-it too could have purchased equipment conforming to the design specifications from another company and resold it to the plaintiff at the contract price. 
Further, the impracticability defense in Waldinger presumably applies equally in actions against the principal contractor. For example, if the plaintiff in Waldinger had refused to finish the plant because its subcontractor could not meet specifications due to the unforeseen denial of a waiver, impracticability seemingly would serve as a defense to an action by the sanitary district. This situation significantly reduces the ability of the sanitary district to rely on competitive bids-after Waldinger, the danger always exists that a bid will have been premised on some assumption about the contracting environment, the incorrectness of which was sufficiently unforeseeable that the bidder need no longer perform if his costs of production have risen substantially.

\section{The Alcoa Case}

Mineral Park, Florida Power, and Waldinger all involve undertakings by the promisor at a fixed price. Frequently, however, parties to longterm contracts include price adjustment or "escalator" clauses in their contracts, which serve to adjust the contract price to market conditions over time. A seller who faces uncertainty about the future price of some essential input, for example, may bargain for a clause that increases the contract price in the event that the price of the input (and thus the seller's cost of production) increases over the life of the contract. Such clauses may serve a risk-allocation function by shifting some or all of the risk of cost fluctuations from a risk-averse seller to the buyer. ${ }^{112}$

But escalator clauses are also found in contracts between large, publicly held companies-risk aversion is at best an uncomfortable explanation for these escalator clauses. ${ }^{113}$ Rather, price escalation here may serve primarily to reduce incentives for opportunistic behavior that might arise under a fixed-price contract. ${ }^{114}$ For example, if production costs increase to the point that the contract is unprofitable to the seller (but still worth performing from a social perspective), the seller may be tempted to breach the contract. The buyer will then have resort to the courts, but that

\footnotetext{
112 The use of escalator clauses to allocate risk is especially common in the labor market-union wage agreements frequently contain escalator provisions to protect workers against a decline in purchasing power. See, for example, Costas Azariadis, Escalator Clauses and the Allocation of Cyclical Risks, $18 \mathrm{~J}$. Econ. Theory 119 (1978); Olivier Blanchard, Wage Indexing Rules and the Behavior of the Economy, 87 J. Pol. Econ. 798 (1979).

113 See discussion of Florida Power above.

114 This analysis is developed much more fully in Goldberg, Price Adjustments, supra note 5; Victor Goldberg \& John Erickson, Quantity and Price Adjustment in Long-Term Contracts: A Case Study of Petroleum Coke, 30 J. Law \& Econ. 369 (1987); Paul Joskow, Price Adjustment in Long-Term Contracts: The Case of Coal, 31 J. Law \& Econ. 47 (1988).
} 
prospect is costly to the buyer. The seller knows this fact and thus expects to be able to settle with the buyer for less than the full amount of expectation damages. Before the settlement is reached, however, both parties would expend considerable resources gearing up for litigation, when it is in their mutual interest to avoid these costs. Similarly, to encourage the buyer to renegotiate an unprofitable fixed-price contract, the seller may be tempted to cheat on quality, delivery times, and the like. Again, the buyer will have recourse to the courts, but the process is costly and the outcome uncertain. In the meantime, considerable efficiency costs attend the seller's behavior, and it is in the interest of both parties to avoid them. An escalator clause designed to ensure that the contract remains profitable for both the seller and the buyer can avoid such opportunistic behavior by the seller, and thus it can generate considerable efficiency gains even if both parties are risk neutral.

The parties, however, must still select a suitable escalation device. The buyer will not likely accept a price tied directly to the seller's costs of production because such a provision dilutes the incentive for cost control and the buyer also has difficulty verifying the accuracy of the seller's claims about his costs. Consequently, the parties are likely to construct some proxy for the seller's costs using information that the seller cannot manipulate-various producer price indices prepared by the Department of Labor are frequent choices.

Alcoa v. Essex Group, Inc. ${ }^{115}$ illustrates the difficulties that can arise when the proxy chosen for the seller's cost of production proves a poor one. Essex entered a tolling agreement with Alcoa, under which Alcoa would take delivery of alumina from Essex and convert it into aluminum for the subsequent manufacture of aluminum wire by Essex. The price to be received by Alcoa was to rise with changes in the producer price index (then "wholesale price index") for industrial commodities. But Alcoa's actual production costs increased at a rate far in excess of the price increases allowable under the escalation formula, due in large part to the rise of the Organization of Petroleum Exporting Countries and the unprecedented inflation in energy costs. Alcoa then sued to reform the contract, and Essex counterclaimed for breach of contract.

The court determined that under the contract as written, Alcoa stood to lose $\$ 60$ million over the life of the contract. It also concluded that the failure of the wholesale price index to track Alcoa's actual costs with reasonable accuracy was a "failure of a basic assumption of the parties." 116 Invoking the doctrines of mistake, impossibility, and frustration,

115499 F. Supp. 53 (W.D. Pa. 1980).

116 Id. at 70. 
the court then reformed the price term in the contract to make it considerably more favorable to Alcoa. ${ }^{17}$

This decision is subject to a number of criticisms, several of which are by now quite familiar. First, both companies were large, publicly held entities, and considerations of risk aversion do not seem to favor shifting the risk of imperfections in the escalator clause from one company to the other. Second, performance of the contract remained efficient despite the increase in costs (indeed, performance was to continue after reformation of the price term), and thus arguments for invoking the impossibility defense based on the need to optimize reliance ex ante, or to induce efficient mitigation following an efficient breach, have no applicability. Third, the decision fails to establish a clear default option for contracting parties-apparently, a $\$ 60$ million loss was enough to make performance impracticable in this case, but the basis for that determination seems little more than a gut feeling on the part of the district judge that losses of that magnitude warrant judicial intervention.

A further criticism follows from the earlier proposition that the function of escalator clauses in contracts between parties like Alcoa and Essex may be to discourage opportunistic behavior. As the Alcoa case illustrates, a poor choice of an escalator may frustrate this objective and lead the disadvantaged party to commit a breach. But the prospect of "equitable reformation" (or discharge) by the courts under these conditions may simply exacerbate the problem. By providing a party to disadvantageous contract with a significant prospect of judicial relief, the temptation to commit a breach and litigate the defense of impossibility (or mistake or frustration) increases, with all the attendant costs to both parties. The problem is doubly compounded when the outcome of litigation is unpredictable, which, as noted, tends to impede settlement. One can argue, therefore, that despite the failure of the contract to accomplish what the parties intended, the courts should simply enforce the contract as written with a minimum of delay and confusion, thereby making clear to the disadvantaged party that opportunistic behavior is unlikely to be profitable.

\section{B. Destruction or Unavailability of the Means of Performance}

As noted, the common-law courts were initially hesitant to invoke the impossibility defense in response to mere increase in the cost of performance. Rather, the early cases applied the defense only when performance was said to be impossible, typically because of the destruction of

${ }^{117}$ Id. at $78-80$. 
the subject matter of the contract or of other tangible property viewed as essential to performance. ${ }^{118} \mathrm{~A}$ subset of these cases is now covered under the U.C.C. by a provision discharging contracts in the event of "casualty to identified goods." 119

The application of the impracticability defense to this class of cases is at least in one respect less problematic than in cases of mere increased cost. The destruction of a factory, ${ }^{120}$ a crop, ${ }^{121}$ or some other tangible item deemed essential to performance is a discrete event for which, in principle, bright line rules may be formulated. A rule that states "if your factory burns down and is a total loss, contracts to supply output from that factory are discharged" does provide intelligible default options for contracting parties.

It is much less clear, however, that such rules supply desirable default options. As this section will suggest, cases involving the destruction of the means of performance also raise difficult issues that courts seem ill equipped to handle and, as a consequence, often handle rather poorly.

\section{The Taylor and Wolf Trap Cases}

Taylor v. Caldwell, ${ }^{122}$ widely regarded as the genesis of the modern impossibility doctrine at common law, involved the destruction of a music hall by fire prior to a series of scheduled concerts. The promoters of the concerts sued the owners of the hall for failure to deliver a suitable facility for the concerts as promised, but the court discharged the obligations of the owners. The continued existence of the hall was held to be an implied condition of the contract. ${ }^{123}$

Taylor does not quite fit the assumptions of the model analyzed in Section I. The event that made performance impracticable-the destruction of the music hall-did not merely increase the cost of providing a concert facility but also represented a substantial casualty loss for the owners of the hall. ${ }^{124}$ Concomitantly, the ex ante risk associated with the destruction of the hall was not simply the risk that the profit from

118 See note 1 supra.

119 See U.C.C. \$2-613.

120 See, for example, Goddard v. Ishikawajima-Harima Heavy Industries Co., 24 N.Y.2d 842, 248 N.E.2d 600 (N.Y. 1969).

${ }^{121}$ See cases cited note 140 infra.

1223 Best \& South 826 (K.B. 1863).

123 Id. at 833-34.

124 Formally, the model in Section I treated the producer's outside wealth, $y$, as fixed. The producer's wealth level could only fall below $y$ if the law forced the producer to pay damages in the event of a breach. Here, by contrast, the destruction of the hall reduces the producer's outside wealth even if damages are zero. 
the concerts in question would be lost but also the risk that the hall would be lost. If such a risk is to be allocated efficiently between the owners and the promoters, and the owners are at all risk averse, it is plausible indeed that optimal risk sharing might require the promoters to bear (at least) the risk of losing their share of the concert profits. Such an allocation of risk still leaves the bulk of the risk on the owners of the hall-they lose their share of the concert profits, plus the value of the hall.

This risk-sharing justification for the decision obviously fails if the owners of the hall were risk neutral and the promoters risk averse-an issue about which one can only speculate. More important, the risk-sharing justification loses much of its force if the hall was insurable. Then, if the owners of the hall were risk averse, an insurance company would likely have been the efficient risk bearer with respect to the risk of losing the hall. The only risk to be allocated between the parties to the contract would then be the risk of losing the profit from the concerts. ${ }^{125}$ Conceivably, the decision in Taylor - which relieves the owners of any obligation to pay damages and relieves the promoters of any obligation to pay for the use of the hall-is a roughly efficient way to split the loss of profits among risk-averse parties. But this justification for the decision is obviously a matter of conjecture.

Equally conjectural would be a reliance or mitigation justification for Taylor. Perhaps in the absence of a prospect of discharge, promoters such as those in Taylor will spend too much advertising the concerts or will lack the incentive to seek out an alternative concert facility (assuming that they are better able to do so than the owners of the hall). Yet it is also possible that the prospect of discharge under the circumstances in Taylor leaves the owners of concert facilities with inefficiently little incentive to take precautions against fires. ${ }^{126}$ Or perhaps the owners are typically better suited than the promoters to arrange for an alternate concert site.

In short, although it is possible that Taylor is an efficient decision, we can have no confidence that it was either on its own particular facts or for concert promoters and concert hall owners in general. Nothing in the report of the case provides the information necessary to a proper assessment of the economic consequences of the decision. More important, nothing in the report of the case suggests that the court was sensitive, even implicitly, to the economic issues that the case poses.

125 Indeed, if the owners can recover the value of the hall from the insurance company, and that value is equal to the present value of expected future net revenues from the use of the hall, one could argue that the owners' share of the concert profits is covered by the insurance policy. The only uninsured risk would then be the promoters' share of the concert profits. The decision in Taylor places that loss entirely on the promoters.

${ }^{126}$ See Bruce, supra note 5, at 323-25. 
The King's Bench can hardly be faulted for its lack of economic sophistication when it decided Taylor in 1863 . Yet, Taylor today retains considerable precedential value and is applied by modern courts with little more reflection on economic concerns than was evident in Taylor itself. An instructive example is Opera Co. of Boston, Inc. v. Wolf Trap Foundation for the Performing Arts, ${ }^{127}$ a case in which the means of performance was not destroyed, as in Taylor, but was incapacitated temporarily. A power outage at an open-air pavillion led to cancellation of an opera performance. The opera company sued to collect the agreed-on fee for its performance, and the owners of the pavillion raised the impossibility defense, citing Taylor and similar decisions. The district court found for the plaintiff on the theory that the defendant was obligated to supply power for the performance, the power outage was readily foreseeable, and the defendant consequently bore the risk that a power outage might force cancellation. The Fourth Circuit reversed, holding that a contingency need not be unforeseeable for the impossibility defense to apply, just "unexpected." 128 It remanded the case for further findings on the question whether the power outage was sufficiently likely that "the obligor should have guarded against it or provided for nonliability against the risk." 129 If not, the impossibility defense would be established. ${ }^{130}$

The analysis in Section I suggests at least three possible objections to the decision in Wolf Trap. The defendant was a nonprofit 501(c)3 organization supported by foundation grants, individual charitable contributions, and government assistance (Wolf Trap is located in a national park). The proposition that risk aversion on the part of the foundation justifies placing the risk of cancellation on the opera company, also a nonprofit entity, seems dubious. ${ }^{131}$ More generally, today the owners of major performance facilities are often states, municipalities, and the like. It seems highly implausible that they require protection from ordinary contract liability in the event of the occasional fire or power failure because of risk aversion.

In addition, the moral hazard problem may have been a serious one. The dissenting judge in the Fourth Circuit made reference to an internal memorandum of the defendant that suggested that power failures had been a relatively frequent occurrence at Wolf Trap, and that recom-

127817 F.2d 1094 (4th Cir. 1987).

128817 F.2d at 1100.

129 Id. at 1103.

130 The litigation was subsequently settled for about 30 cents on the dollar.

131 To be sure, the Wolf Trap Foundation also loses income from canceled performances, and thus the impossibility defense serves to split losses between the foundation and the performers. Whether that split of the losses is efficient is purely a matter of conjecture. 
mended the installation of a back-up power generator to allow performances to continue in the event of a power failure. The memorandum further observed that such generators were in use in theaters around the country and were "not a major investment."132 Alternatively, the defendant might have arranged to obtain back-up generators from the local civil defense authorities. ${ }^{133}$ Whether a back-up power supply would have sufficed for the performance to go forward on the night in question is unclear, ${ }^{134}$ but a careful examination of that issue was certainly warranted prior to discharge. The issue to be resolved on remand-whether the power outage was sufficiently likely that the defendant should have guarded against it-is at best an incomplete statement of the relevant issues.

An information question also arises. If many theaters around the country have emergency generators, the opera company may well have imagined that the Wolf Trap pavillion would have one as well. To discharge the obligations of the foundation in the face of asymmetric information about the added risk of cancellation due to the absence of a back-up power supply creates potential inefficiencies, as discussed in Section I.

\section{The Asphalt International Case}

Asphalt International, Inc. $v$. Enterprise Shipping Corp. ${ }^{135}$ provides another modern illustration of the difficulties that may arise in cases where the means of performance is destroyed or temporarily incapacitated. The defendants' tanker was damaged in a collision with another vessel. The defendants obtained an estimate of repairs that exceeded the market value of the tanker and declared the vessel a total loss. Defendants then collected on their marine insurance policy an amount in excess of the market value of the tanker prior to the accident, plus an additional amount when the vessel was sold for scrap. As a consequence, defendants profited from the accident by nearly $\$ 1$ million. ${ }^{136}$ Defendants had assumed the obligation to repair the vessel in their charter agreement with plaintiffs, and plaintiffs sued for breach of contract when the defendants refused to perform repairs. The court determined that repair was commercially impracticable- the cost to repair the vessel was "excessive

132 Id. at 1104

133 Id.

134 Part of the reason for cancellation was a concern for public safety in the darkened parking lot and pathways through the park. Id. at 1103 . Whether a back-up generator could have provided the necessary lighting for these areas, at reasonable cost, is unclear.

135667 F.2d 261 (2d Cir. 1981).

136 Id. at 266. 
and unreasonable"' because it considerably exceeded the market value of the vessel prior to the accident.

A possible justification for the decision rests on information. Presumably, the charterers are in a better position to know what the loss of the vessel will cost them and to purchase the appropriate amount of insurance if they are risk averse. But the analysis is not quite so easy. The vessel was considerably overinsured by its owners, a practice uncommon in most insurance markets but not unfamiliar with marine insurance. ${ }^{137}$ The ability of vessel owners to overinsure suggests that they may readily purchase coverage to protect the charterers of the vessel, and it may well be more economical for the contracting parties to purchase a single insurance policy rather than two. Further, the fact that the owners of the vessel were considerably overinsured, by an amount almost as great as the damages claimed by plaintiffs, suggests that risk aversion on the part of the owners did not justify shifting the loss to the charterers.

Finally, overinsurance created a serious moral hazard problem. The incentive for the defendants to obtain a repair estimate that exceeded the market value of the ship became quite powerful and, indeed, the plaintiffs contested its accuracy. ${ }^{138}$ In such cases, if the court cannot ascertain the true cost of repairs with a high degree of confidence, discharge of the defendants' obligations creates a danger of inefficient breach. ${ }^{139}$

\section{Crop-Failure Cases}

If the seller of an agricultural product refuses to meet his contractual obligations as a result of a crop failure, the impossibility defense may discharge those obligations. In particular, if the contract calls for the delivery of crops grown on a particular tract of land, and weather conditions or other natural forces cause the crop on that land to fail or the yield to fall below expected levels, the contract will be discharged to the extent that the yield is inadequate to fulfill it. ${ }^{140}$ If the contract does not specify the land on which the crop is to be grown, however, the impossibility defense will not apply. ${ }^{141}$

137 See id. at 264 n.3.

138 Id. at 264.

139 Here, inefficiency arises if the combined wealth of the owners, the charterers, and the owners' insurance company is not maximized.

${ }^{140}$ See Pearce Young Angel Co. v. Charles R. Allen, Inc., 213 S.C. 578, 50 S.E.2d 698 (1948); Squillante v. California Lands, Inc., 5 Cal. App. 2d 89, 42 P.2d 81 (1935); Matousek v. Galligan, 104 Neb. 731, 178 N.W. 510 (1920); Paymaster Oil Mill Co. v. Mitchell, 319 So.2d 652 (Miss. 1975); Campbell v. Hostetter Farms, Inc., 380 A.2d 463 (Pa. Super. Ct. 1977).

${ }^{141}$ See United Sales Co. v. Curtis Peanut Co., 302 S.W.2d 763 (Tex. Civ. App. 1957). If the contract is silent about whether a particular tract of land is contemplated, courts may 
The distinction between the two classes of cases again owes to the historical insistence at common law that performance be physically impossible. If the contract required crops to be grown on particular land, and those crops did not exist due to a crop failure, then performance was viewed as impossible. But if the contract was not linked to a particular tract of land, the seller could perform by purchasing goods in the spot market and reselling them to the buyer. This distinction, of course, is artificial because even if the contract contemplates the sale of crops off particular land, the seller might still meet his obligations in the event of a crop failure by purchasing the goods in the spot market and reselling them under the contract-rarely are agricultural goods so unique in their characteristics that adequate substitutes are not available on the open market.

Posner and Rosenfield agree that the common-law distinction is artificial, but they argue that it serves as a rule of thumb for distinguishing cases in which the seller is a farmer from cases in which he is a wholesaler ${ }^{142}$ If the contract relates to crops grown on particular land, they suggest, the seller is likely to be a farmer. They further argue that discharge of a farmer's obligations is likely to be efficient because the buyer is typically a processor that can diversify risk by contracting for supplies from diverse geographic areas. But if the seller is a wholesaler, the seller has the same ability to diversify as the buyer and discharge is unnecessary. ${ }^{143}$

This argument is certainly not without merit. When a crop fails, the loss to the contracting parties is equal to the market value of the crop. If the contract is discharged under the impracticability defense, this loss is divided as follows: the farmer loses the contract price, and the buyer loses (gains) the amount by which the current market price exceeds (falls short of) the contract price. Because crop failures ordinarily affect a number of farms, the occurrence of a failure may indeed be correlated with market conditions in which current prices exceed the contract price, and hence buyers will likely be disadvantaged by discharge on average. Yet, the loss to the buyer will still be far less than the loss to the farmer in most cases. If buyers are generally risk neutral and farmers are generally risk averse, it is not at all implausible that such a limited allocation of risk to the buyer might Pareto dominate the expectation damages rule, which allocates all of the risk to the farmer. ${ }^{144}$

\footnotetext{
allow parol evidence to clarify the understanding of the parties. See Snipes Mountain Co. v. Benz Brothers \& Co., 162 Wash. 334, 298 P. 714 (1931).

142 Posner \& Rosenfield, supra note 4, at 107.

${ }^{143}$ Id. at 106-7.

144 This proposition can be shown formally under restrictive assumptions about the structure of the problem. See the appendix, section 7.
} 
Nonetheless, the Posner-Rosenfield analysis of these cases is open to debate. The results in Section I, along with previous results derived by Perloff, ${ }^{145}$ suggest that risk aversion on the part of farmers and risk neutrality on the part of buyers ${ }^{146}$ may not always suffice to guarantee the optimality of discharge as a risk-sharing device. More important, the assumption that buyers are better risk bearers than farmers is certainly not correct in all cases. The seller, though a farmer, may be an agribusiness conglomerate. Or the seller may simply be quite wealthy and, thus, fairly well able to bear the risk of a single crop failure. ${ }^{147}$ The buyer, by contrast, may be a small, local processor or retailer, making purchases from a limited geographic area. The limited geographic scope of the buyer's purchases may make it impossible for him to diversify fully the risk of nonperformance due to adverse weather conditions, which to some degree may affect all farmers in the region. Likewise, the limited volume of the buyer's purchases may make it impossible for him to diversify risk effectively - the law of large numbers does not apply when the numbers are not large. For all of these reasons, a discharge of farmers' obligations in the event of a crop failure need not provide significant risk-sharing benefits.

These concerns are not merely hypothetical. In Alimenta, Inc. v. Gibbs Nathaniel Canada, Ltd. ${ }^{148}$ for example, the court mechanistically applied familiar doctrine to discharge the obligations of the seller even though the seller was not a farmer, and, indeed, both parties to the contract were "international dealer(s) in agricultural commodities." 149 The proposition that discharge of the contract can be justified by considerations of risk aversion in such a case seems speculative at best.

Moreover, discharge in the crop-failure cases may create potentially serious moral hazard problems. If poor crop yield may result from excessive rainfall, perhaps measures to improve drainage might be taken. If poor crop yield may result from inadequate rainfall, perhaps measures to

\footnotetext{
145 Perloff, supra note 5, makes the point in a model that analyzes forward contracts between risk-averse farmers and risk-neutral buyers. That model is subject to criticism, however, in that its depiction of the impracticability defense bears no relation to reality. Perloff imagines that the defense operates to discharge forward contracts if the spot price rises "too high" or falls "too low." In fact, of course, a discharge of the performance obligation at common law depends on the occurrence of a crop failure, which may or may not correlate with a significant increase in spot prices. And nothing in the common law would discharge the obligations of buyers or sellers in the event of a bumper crop that drives spot prices exceptionally low.

${ }^{146}$ The Posner \& Rosenfield proposition, note 4 supra, that buyers can diversify the risk is, for purposes of analysis, equivalent to the proposition that buyers are risk neutral.

${ }^{147}$ See note 38 supra (hypothesis of decreasing absolute risk aversion).

148802 F.2d 1362 (1986).

149 Id. at 1362.
} 
conserve water in storage ponds and to improve irrigation facilities might be taken. Or perhaps the farmer will have the option to purchase water for irrigation using existing irrigation facilities and must decide how much water to purchase. As long as the buyer captures part of the surplus from the contract-as he generally will, especially when adverse weather conditions create local crop shortages-discharge may inefficiently reduce the incentives for farmers to take such measures. The case law is inattentive to this issue and in no way intimates that discharge is contingent on a finding that the farmer has taken all cost-effective measures to avoid a reduction in crop yield. Crop failures are not just acts of God.

Finally, it is not difficult for the contracting parties to provide expressly for discharge when it is efficient. The possibility of a crop failure is hardly the sort of event that will escape the contemplation of the average farmer. It is the bane of every farmer's existence. And, a contractual provision to relieve the farmer wholly or partially of the obligation to perform in the event of inadequate crop yields is not difficult to craft-a sentence or so will do the trick. When the transaction costs of inserting an express discharge provision are seemingly so low, perhaps its absence warrants an adverse inference about its efficiency.

In sum, while the results in the crop-failure cases may on average be efficient, we cannot be sure. Further, doctrine is seemingly blind to the case-specific factors that bear mightily on the optimality of discharge. Perhaps current doctrine may be defended on the grounds that it creates a reasonably bright-line rule, which on average produces an efficient result and which cannot be improved on because courts are rather inept at assessing case-specific factors accurately, or because such an assessment would be too costly. But once again, the proposition that existing law promotes efficiency requires a significant leap of faith.

\section{Ex Post Efficiency and the Impracticability Defense}

The legal and economic discussion to this point assumes that the impracticability defense enters the contracting parties' assessment of their ex ante welfare and affects the ex ante allocation of resources. In some cases, however, the relevant contingencies are so wildly improbable that the parties may not consider them at the time of contracting.

Indeed, black-letter statements of the impracticability defense often suggest that the defense applies only to contingencies that are unforeseeable, unforeseen, or unexpected. The U.C.C. commentary, for example, restricts the defense to cases involving some "unforeseen contingency." 150 The Second Restatement of Contracts states that performance

${ }^{150}$ U.C.C. $\S 2-615$, comment 4 (1972). 
must "unexpectedly become impracticable." 151 The cases vary as to their emphasis on a requirement of unforeseeability, but even where a strict requirement of unforeseeability is rejected, ${ }^{152}$ the courts generally insist that the contingency in question must have appeared highly improbable ex ante.

The rationale for this requirement is clear. The impracticability defense applies only when the contract is silent about the allocation of the risk at issue-an express allocation of risk will always trump. The inference that the price term was understood by the parties to assign the risk of cost fluctuations expressly is weakened when the cost increase is extraordinarily large and results from some event that would have seemed highly improbable at the time of contracting. Thus, the foreseeability test and its variants serve as an aid to construction-it allows the court to make an inference of contractual silence regarding the allocation of the risk in question.

But the result may often be to limit the impracticability defense to contingencies that are truly unforeseen or that are perceived as so improbable ex ante that it is not worth the effort to forecast the operation of the legal default option. To that extent, the defense will have no systematic effects on ex ante resource allocation. It then makes little sense to design the impracticability defense to maximize ex ante welfare-ex post welfare maximization becomes a more appropriate objective. ${ }^{153}$ Of course, ex post welfare maximization holds little interest if the legal rule merely divides a fixed loss between the parties. Aggregate wealth is then unaffected by the liability rule, and no one division of the loss Pareto dominates any other division. But if the materialization of the contingency at issue generates costs that are avoidable through an appropriate choice of the legal rule, ex post welfare maximization is nontrivial.

At this point, however, the analysis returns to issues that have already been considered. The costs of inefficient breach by the seller arise ex post, and the expectation damages rule has the virtue that it encourages the seller to perform if and only if performance is efficient. The costs of dispute resolution also arise ex post and tend to increase as the predictability of dispute resolution declines-as noted, the impracticability defense is often anything but a bright-line rule for dispute resolution, and

151 Restatement (Second) of Contracts $\$ 261$, comment a.

152 Compare Opera Co. of Boston, Inc. v. Wolf Trap Foundation for the Performing Arts, 817 F.2d 1094, 1100 (4th Cir. 1987) (rejecting unforeseeability as a prerequisite to impracticability) with Waldinger Corp. v. CRS Group Engineers, Inc., 775 F.2d 781 (7th Cir. 1985) (suggesting that foreseeability is the critical test).

${ }^{153}$ Here, "ex post" refers to the period after the parties realize that the cost of performance has risen. 
the expectation damages rule then provides considerably greater predictability.

One cost that arises ex post, and that in the abstract might provide an argument for the impracticability defense, is the cost of inefficient mitigation of damages by the buyer. But once again, it is difficult to see how the courts can weigh the benefits of more efficient mitigation against the offsetting costs. It is equally clear that nothing in the case law reflects a concern for efficient mitigation by the buyer. Hence, the weakness of the impracticability defense ex ante is not cured by examining it ex post.

\section{ConClusion}

A discharge of contractual obligations following an increase in the cost of performance may, under certain conditions, implement a second-best allocation of cost fluctuations between contrasting parties. Among other things, the prospect of discharge may improve the efficiency of risk sharing, discourage excessive reliance by the promisee, or encourage proper mitigation of damages. But it is exceptionally difficult to formulate a default rule of contract law that limits discharge to the circumstances in which it is efficient-to administer such a rule, the courts will typically require more information than is reasonably available to them.

Not surprisingly, therefore, the efficiency of the impracticability defense in practice is open to question. The survey of the case law above is admittedly selective and hardly exhausts the range of possible circumstances to which the impracticability defense may apply. Nonetheless, it suggests that the courts tend to focus almost exclusively on the burdensomeness of performance to the promisor and the foreseeability of the contingency that makes performance burdensome. Yet, no set of plausible assumptions about the contracting parties justifies such a narrow focus. Important factors that the courts omit from systematic consideration include the relative risk-bearing capacities of the contracting parties, information conditions, and various moral hazards. These omissions may be unavoidable because of information constraints. But if so, the utility of an impracticability defense is in doubt, at least for the classes of cases discussed here.

To say that existing law is flawed, however, is not to say that superior alternatives are immediately apparent. The analysis in this article does not establish that discharge of contractual obligations under the impracticability defense is always inefficient, merely that the efficiency of discharge is exceptionally difficult to ascertain. Indeed, there are at least some types of cases (such as the crop-failure cases) in which the analysis suggests that the defense may on average be efficient, even though it 
is impossible to be sure. Thus, the analysis does not support a proposal for general abolition of the impracticability defense.$^{154} \mathrm{~A}$ promising direction for reform lies in developing clear rules to cover well-defined categories of cases, such as the rules that presently govern the supervening illegality cases, the crop-failure cases, and cases of casualty to identified goods under the U.C.C. To this end, one option would be to abolish the impracticability defense except in those cases now governed by brightline principles. Thus, for example, the defense might be abolished for increased cost cases such as Mineral Park or perhaps restricted to a bright-line, and concededly somewhat arbitrary, threshold for discharge-for example, a 500 percent increase in cost above some observable benchmark. To be sure, there can be no basis for confidence that any particular threshold is best, but at least a bright-line rule would provide contracting parties with an intelligible default option ex ante and reduce litigation costs ex post.

Another option, potentially applicable to all impracticability cases, would be to focus on the characteristics of the defendant and to refuse to discharge the contract whenever the defendant is, for example, a publicly held corporation or government agency. The risk-sharing justification for discharge is especially weak in these cases and, as argued earlier, the reliance and mitigation justifications for discharge are perhaps beyond the capacity of the courts to implement efficiently. Further, large companies and government agencies are typically represented in contract negotiations by experienced counsel who can, in the absence of an impracticability defense, assume a greater obligation to specify expressly the contingencies under which performance is to be excused.

These proposals are obviously quite tentative. As is often the case, it is far easier to identify imperfections in existing doctrine than to craft demonstrably superior alternatives. But it is also difficult to imagine that the existing state of affairs, in which many cases are governed by highly unpredictable rules that are devoid of any apparent economic foundation, is the best that we can do.

\footnotetext{
${ }^{154}$ Moreover, some of the problems with the defense would simply resurface elsewhere. Contracting parties often include vague force majeure clauses in their contracts, for example, and the courts cannot avoid the need to construe them in the event of disputes. Likewise, even in the absence of an impracticability defense, contracting parties can always urge that contracts be construed to incorporate certain implied terms-for example, an implied term that personal services contracts terminate on the death of the promisor. Thus, any curtailment or abolition of the impracticability defense would to some extent simply shift the battleground and confront the courts with the same issues in a different context.
} 